\title{
Artikkeli
}

\section{Kirja-arvostelut alustataloudessa - esimerkkinä käyttäjälähtöiset arvostelut Instagramissa}

\begin{abstract}
Kulttuurituotteita eivät sosiaalisen median aikakaudella enää arvostele julkisesti vain perinteisen median ammattikriitikot, vaan myös tavalliset inmiset osallistuvat teosten julkiseen arvottamiseen erilaisilla digitaalisilla alustoilla. Tarkastelemme tässä artikkelissa kirjallisuusarvosteluja osana alustoitunutta kulttuurituotantoa esimerkkinämme käyttäjälähtöiset kirja-arvostelut erityisesti kuvasovellus Instagramissa. Instagramiin on vakiintunut kirjallisuuskeskusteluyhteisö, jota kutsutaan maailmanlaajuisesti nimellä Bookstagram mutta jolla on myös paikallisia tai alueellisia muotoja, kuten suomalainen Kirjagram. Kysymme, miten käyttäjäarvostelijat esiintyvät niissä arvostelulle määritellyissä funktionaalisissa rooleissa, jotka on aiemmassa tutkimuksessa havaittu perinteisten kriitikoiden toiminnassa. Erilaisten asemoitumisten perusteella hahmottelemme eroa kulttuurisen intermediaation ja kulttuurisen intramediaation käsitteiden välillä, joiden väitämme keskeisimmin kuvaavan eroa institutionaalisen ja käyttäjälähtöisen kirja-arvostelun välillä sekä samalla kuvaavan alustoituneen kirjallisuusarvostelun erityislaatuisuutta.
\end{abstract}

AVAINSANAT: kulttuurinen alustatalous, kirjallisuusarvostelu, käyttäjälähtöinen sisällöntuotanto, kulttuuriset välittäjät

K irjallisuuden vastaanotto ennen sosiaalisen median aikakautta oli karkeasti kaksijakoista: Mediavälitteisessä institutionaalisessa julkisuudessa kirjoja ja muita kulttuurituotteita arvostelivat sanoma- ja aikakauslehtien palkkaamat kriitikot, joilla oli julkinen etuoikeus määrittää uuden kulttuurin arvo ja laatu. Kirjallisuuden lukijakunta, joka oli myös joukkoviestinten välittämien arvosteluiden lukijakuntaa, arvotti kirjallisuutta sosiaalisesti erilaisissa yhteisissä kohtaamisissa, kuten työ- ja vapaa-ajan kontakteissa, kirjallisuuspiireissä sekä tilanteissa, joissa omaa elämäntyyliä oli mahdollisuus viestittää toisille. Arjen medioituminen ja sosiaalisen median kehitys on tehnyt tavallisten ihmisten elämäntyylien ilmaisemisen mediavälitteisessä julkisessa tilassa mahdolliseksi, ja kulttuurituotteiden arvostelemisesta on tullut yksi käyttäjälähtöisen sisällöntuotannon lajityyppi. Dataistuneen 
median aikakaudella ei-ammattimaisten toimijoiden mahdollisuudet tuottaa ja jakaa sisältöä kirjoista ja omista lukukokemuksistaan eri alustoilla johtavat uusiin tapoihin määrittää kirjan tai yksittäisen teoksen kulttuurista, symbolista ja sosiaalista arvoa. Ne täydentävät ja osittain kenties myös haastavat institutionaalista kritiikkiä ja arvostelutoimintaa.

Tässä artikkelissa tarkastelun kohteenamme on kulttuurinen alustatalous, ja kysymme, miten käyttäjäarvostelut toimivat osana alustoitunutta kulttuurituotantoa. Pureudumme aiheeseen mobiilikuvasovellus Instagram esimerkkinämme. Käyttämällä hyväksi alustojen erilaisia affordansseja käyttäjäarvostelijat tuottavat arvottavia viestejä lukemistaan ja markkinoilla olevista kirjoista. Samalla käyttäjäarvostelijat asettuvat osaksi alustatalouden logiikkaa kuten muutkin käyttäjälähtöiseen sisällöntuotantoon perustuvien digitaalisten alustojen käyttäjät. Haluamme hahmottaa käyttäjälähtöisen arvostelutoiminnan erityisyyttä ensinnäkin omana lajityyppinään alustatalouden kierrossa, jossa arvostelua ei ole rakentavaa niputtaa yhteen kaikkien muiden käyttäjälähtöisten sisältöjen kanssa, ja toiseksi Instagram-alustalla, joka kuvavetoisena mediumina poikkeaa kaikista edeltävistä arvostelutoiminnan muodoista siinä, että se perustuu ensisijaisesti visuaaliseen estetiikkaan. Tarkastelemalla kirja-arvosteluja erityisenä alustatalouden muotona pääsemme siis käsiksi siihen, minkälaista käyttäjälähtöinen ei-institutionaalinen arvostelutoiminta on.

Arvostelun tehtävänä on esitellä, tulkita ja arvottaa kulttuurin markkinoiden uusia tuotteita (Blank 2007). Kulttuurituotteita on arvosteltu digitaalisilla alustoilla jo internetin alkuajoista lähtien, jos ajatellaan, että kirjallisuudesta kyettiin keskustelemaan jo "purkkien" eli Bulletin Board Systemsien, lankapuhelinverkkoon liitettyjen kotitietokoneiden tai 1988 perustetun IRC:n eli Internet Relay Chatin sosiaalisissa yhteisöissä. Käsitämme arvostelun (review) kuitenkin omanlaiseksi lajityypikseen (ks. esim. Blank 2007), joka edellyttää julkisen sisällöntuottajan tunnistautumista arvostelijaksi eli tietynlaisen tuottajaidentiteetin omaksumista. Tyypillisesti tuottaja myös itse nimeää tuottamansa tekstit arvosteluiksi. Arvosteleminen on myös tavoitteellista ja pitkäaikaista toimintaa, eli arvostelija pyrkii seuraamaan kulttuurin jotain osa-aluetta enemmän tai vähemmän systemaattisesti. Pitkäaikaisuuden vuoksi arvostelun genrelle on vakiintunut tietty diskurssi ja tietyt jaetut käytännöt (Orlik 2016). Vaikka käyttäjälähtöinen arvostelutoiminta on alhaalta ylöspäin rakentuneena sosiokulttuurisena ilmiönä paljon heterogeenisempi ja ennakoimattomampi kuin mediaorganisaatioiden ohjailema institutionaalinen arvostelutoiminta tai kritiikki, arvostelu alustoilla edellyttää jonkinasteista vakiintuneisuutta. Käyttäjälähtöisiä kirjallisuusarvosteluita esiintyy säännöllisesti kirjallisuusblogeissa (ks. esim. Steiner 2010), lukemiskulttuureille omistetuilla kirjallisuusfoorumeilla (esim. Goodreads) ja tuotearvioina kirjakauppaalustoilla (esim. Amazon, Google Customer Reviews). Näille foorumeille on yhteistä, että arvostelu käsitetään omaksi erilliseksi genrekseen ja tekstikäytännökseen. Tämän lisäksi internetin eri alustoja ja teknologioita hyödyntävä kirjakulttuuri, johon viitataan esimerkiksi nimellä bookternet ("kirjaternet"), on laaja, ja arvosteluita julkaistaan myös sosiaalisen median sovelluksissa. Kirjallisuudesta keskustellaan lähestulkoon kaikilla julkisia yhteisöjä muodostavilla digitaalisilla alustoilla - Facebookissa, Twitterissä, Pinterestissä, TikTokissa tai vaikkapa fanfiction-foorumeilla. Arvostelut tulee kuitenkin erottaa tällaisesta kirjallisuuskeskustelusta (ks. esim. Boot 2011), jota englannin kielessä luonnehditaan termillä bookish, "kirjamainen". Kirjamaisuus on siten kaikkea kirjoihin liittyvää sisällöntuotantoa koskeva termi, joka saattaa tarkoittaa esimerkiksi kirjan esittelemistä sisustusesineenä tai 
keskustelua, joka ei edes suoranaisesti liity kirjoihin saati kirjallisuuteen. Kaikki kirjamainen sisältö ei ole kirjojen arvostelua, vaan arvostelutoiminta on selkeästi erotettava ja vain pieni, määrällisesti mitattuna jopa marginaalinen, osa kirjamaisuutta eli medioitunutta kirjoihin liittyvää elämäntyylien politiikkaa.

Käyttäjälähtöisiä kirja-arvosteluita on tarkasteltu yksittäisillä alustoilla, kuten kirjablogeissa (Steiner 2010), kirjallisuusarvostelufoorumeilla (Verboord 2010) ja YouTubessa, jossa kirjallisuusaiheista käytetään käsitettä BookTube tai KirjaTube (Tomasena 2019) sekä Instagramissa, jossa kirjallisuusaiheista käytetään yhteisönimeä Bookstagram tai Kirjagram (Jaakkola 2020b, 2019). Huomio näissä tutkimuksissa on ollut amatöörimäisen sisällöntuotannon piirteissä erotuksena ammattiarvostelijoiden tuottamasta kritiikistä (Kammer 2015; Steiner 2008, 2010). Tähän mennessä ei ole systemaattisesti tarkasteltu, minkälaisena arvostelu yleisemmin näyttäytyy alustataloudessa ja miten arvostelijat niveltyvät osaksi alustojen kaupallista logiikkaa, johon myös kirjojen jakelu- ja välitystoiminta nivoutuvat (Murray 2018). Tämä on erityisen polttava kysymys kirjallisuuden ja muiden taideja kulttuurituotteiden arvottamisessa, koska arvostelun lajityypin tunnusmerkki on ollut arvostelijan riippumattomuus. Koko arvostelun kulmakivenä on ollut ajatus kolmannen, riippumattoman osapuolen tarjoamasta arviosta. Toisin sanoen arvostelu, joka on liian läheisesti kytköksissä tuotteen tuotanto- ja jakelurakenteisiin, on perinteisesti ymmärretty laadultaan kehnoksi. Tämä on pitkälti pätenyt myös käyttäjäarvosteluihin, joissa tavallisen kulttuurinkuluttajan tuottama autenttinen ja rehellinen kokemus on ollut arvostelun perimmäinen tavoite. Alustataloudessa arvostelun määritelmä tuntuukin asettuvan koetukselle, ja on kiinnostavaa pohtia, miten esidigitaaliselta aikakaudelta nouseva arvostelun käsite määrittyy tässä ympäristössä mahdollisesti aivan toisella tavalla. Voidaanko arvostelulle kuitenkin löytää sitä tuottavien sosiaalisten yhteisöjen sisältä uudenlaisia merkityksiä, jotka tunnistavat ja tunnustavat käyttäjälähtöisen arvostelun arvon ilmiön omin ehdoin?

Alustataloudella tarkoitetaan sisältöjen tuotantoa, julkaisua ja jakamista sekä niihin kohdistuvaa vuorovaikutusta ympäristöissä, alustoilla, joissa alustan tarjoaja luo kanavan ja mahdollistaa viestinnän käyttäjien välillä (Nieborg ja Poell 2018, van Dijck ja Poell 2018, Helmond 2015). Alustat muuntavat, ohjaavat ja muovaavat viestintää merkittävällä tavalla ja ohjailevat myös demokraattisia prosesseja (Gillespie 2019, van Dijck 2014, van Dijck ja Poell 2018). Ne tarjoavat käyttäjille affordansseja eli tarjoumia ja erilaisia viestintää mahdollistavia ja rajoittavia toimintoja, joita hyödyntäen käyttäjät luovat sisältöjä ja vuorovaikutusta sekä näihin liittyviä merkityksiä. Affordanssilla eli tarjoumalla tai käyttömahdollisuudella tarkoitetaan Gibsonin (1979) alkuperäisen määritelmän mukaisesti teknologioihin rakennettuja mahdollisuuksia, jotka mahdollistavat (afford) erilaisia toimintoja käyttäjille ja samalla myös rajoittavat sitä, mitä alustoilla on mahdollista tehdä. Oikeastaan puhuttaessa tarjoumista, joita tarkastelemme tässä artikkelissa, pitäisi puhua havaituista ja toteutuneista affordansseista (ks. Jaakkola 2019), joita yksittäiset sisällöntuottaja-käyttäjät (produsers) hyödyntävät yhteisöissään. Vaikka alusta tarjoaa tietynlaisia affordansseja, käyttäjien on ensin havaittava affordanssit ja alettava hyödyntää niitä jollain yhteisesti hyväksytyllä tavalla yhteisöissään, ennen kuin affordanssit todentuvat. Affordanssit muodostavat siten arvostelujen tuotantokontekstiin lukeutuvia järjestelmiä, jotka määrittävät, mitä yksittäisen sisällöntuottajan on mahdollista tehdä (mahdollistava funktio) ja mikä ei ole mahdollista tai vaatii kompromisseja tai kiertokäytänteitä (rajoittava funktio). Alusta- 
talouden arvostelut ovat siis riippuvaisia valitun alustan viestintä- ja vuorovaikutusmahdollisuuksista: esimerkiksi videoarvostelu on mahdollista rakentaa kestoltaan erimittaiseksi YouTubessa, TikTokissa, Instagram Storyssä tai Instagramin pidempien videoiden esityskanavalla IGTV:ssä, ja video todennäköisesti muovautuu näillä alustoilla myös estetiikaltaan erilaiseksi.

Dataistuminen on digitaalisuuden uusi vaihe, joka muuntaa lähes kaikkia elämänalueita mitattaviksi hyödykkeiksi, dataksi. Ryhtyessään käyttäjäksi jollakin alustalla käyttäjä tuottaa dataa, jota yritykset voivat hyödyntää ja jonka siksi on sanottu olevan digitalouden uusi valuutta, kulta tai öljy (van Dijck 2014, Couldry ja Mejias 2019). Dataistuminen on siten digitaalisen aikakauden tapa hallita maailmaa (Couldry ja Mejias 2019, 135). Käyttäjädatasta, kuten arvostelujen sisällöistä, tai arvostelujen saamasta huomiosta, kuten tykkäyksistä ja kommenttien määrästä, voidaan tehdä johtopäätöksiä siitä, mistä tietty kuluttajaryhmä pitää. Suoraviivaisten johtopäätösten vetäminen ei toki kirjallisuuden kentällä ole järkevää samalla tavoin kuin silloin, kun kyseessä ovat kulutustuotteet - esimerkiksi liikuntavälineet tai vaatteet - mutta kirjallisuuden kuluttajat saattavat kiinnostaa myös kirjallisuuteen ja kulttuuriin välillisesti liittyviä tuotemarkkinoijia ja mainostajia. Arvostelijat toimivat myös vaikuttajamarkkinoinnin kontekstissa, osa tietoisesti, osa haluamattaan. Osa arvostelijoista saattaa esimerkiksi solmia kaupallisia yhteistyösuhteita yritysten kanssa ja markkinoida tuotteita, joko kirjallisia tai ei-kirjallisia. Läheskään aina käyttäjäarvostelijat eivät kuitenkaan tarkalleen ottaen tiedä, millä perusteella ja miten kirja-arvostelujulkaisujen ja tykkäysten mittaaminen oikeasti tapahtuu, niiden algoritminen logiikka kun ei avaudu käyttäjille. Käyttäjälähtöistä sisällöntuotantoa ohjaavat algoritmit ovat luonnollistuneet - ne "vain ovat", jotenkin ne "vain toimivat" (Hepp 2020, 76).

Seuraavaksi esittelemme tutkimuskysymykset, aineiston ja menetelmän. Analyysimme on kaksiosainen. Ensin tarkastelemme alustataloutta arvosteluekologiassa makrotasolla. Tunnistamme kaksi alustatalouden muotoa: institutionaaliset amatööriarvostelujen alustat ja ei-institutionaaliset sosiaalisen median arvostelualustat. Esitämme, että dataistuminen näkyy näissä kahdessa eri alustatyypissä eri tavoin. Tämän jälkeen luomme katseemme jälkimmäiseen tyyppiin, sosiaalisen median arvostelualustoihin, esimerkkinämme Instagram, ja tarkastelemme Instagram-arvostelijoiden funktionaalisia rooleja.

\section{Tutkimuskysymykset}

Tarkastelumme kohteena on alustoitunut kirjakulttuuri ja erityisesti kirjojen arvosteleminen. Olemme kiinnostuneita siitä keskinäisriippuvuudesta, joka on muodostunut alustatalouden imperatiiviksi: miten käyttäjät käyttävät alustaa ja miten alustat käyttävät käyttäjiä. Tutkimuskysymyksiä on kaksi: 1) Miten alustat hyödyntävät käyttäjiä datana kirja-arvostelukulttuurin kontekstissa eli minkälaiset ovat kirja-arvostelun alustatalouden rakenteet? 2) Miten käyttäjäarvostelijat käyttävät Instagram-alustaa asemoiden itsensä erilaisiin arvostelijarooleihin?

Ensimmäinen kysymys sijoittuu makrotasolle ja kuvaa arvostelujen alustalouden rakenteita. Ymmärtääksemme kirja-arvostelun alustataloutta kysymme, millä tavalla alustantarjoaja saa arvostelutoiminnasta lisäarvoa. Kulttuurisesta alustataloudesta piirtyy arvostelu- 
toiminnan kontekstissa tällöin kuva makrorakenteista, jotka ohjaavat keskeisesti arvostelutoimintaa ja poikkeavat perinteisestä arvostelutoiminnasta, jonka ohjailevana voimana toimivat ensisijaisesti journalismia tuottavat mediaorganisaatiot. Toinen kysymys paikantuu meso- tai mikrotasolle. Se liittyy arvostelijoiden lajityyppispesifisiin rooliodotuksiin ja alustojen affordanssien hyödyntämiseen noiden rooliodotusten täyttämiseksi yhdellä erityisellä alustalla. Kysymme toisin sanoen, miten käyttäjäarvostelijat Instagramissa hyödyntävät alustan affordansseja toteuttaakseen arvostelun genreen liitettyjä piirteitä ja asemoituakseen tietynlaisiin arvostelijarooleihin valitulla alustalla.

Ensimmäiseen kysymykseen pyrimme vastaamaan teoreettis-deskriptiivisesti kuvaten keskeisiä käyttäjäarvostelualustojen toimintaperiaatteita. Toiseen kysymykseen vastataksemme kuvaamme aineistosta nousevia piirteitä. Aineistoa on analysoitu primääriaineistona yksityiskohtaisemmin aiemmissa yhteyksissä (Jaakkola 2019, 2020a, 2020b, Jaakkola ja Räisä 2019). Tässä artikkelissa tarkoituksenamme on siten luoda synteesiä, joka johdattaa tarkastelun painopistettä tapaustutkimuksista kohti laajempaa näkökulmaa.

Lähtökohtanamme on arvostelua koskevassa kirjallisuudessa esitetty ajatus, että kirja-arvostelijat toimivat kulttuurisina välittäjinä (cultural intermediaries) (Bourdieu 2010 [1979]), joiden tehtävänä on asettua välikädeksi kulttuurisessa arvonmuodostusketjussa ja tuossa välikäden asemassa rakentaa symbolista lisäarvoa kulttuurin tuotteille (Jones, Berry ja Long 2019, Hutchinson 2017, Maguire ja Matthews 2014). Välittäjäfunktiota on kuvattu myös englanninkielisillä käsitteillä brokers, mediators (Prinsloo ja Breier 1996) ja boundary spanners (Wenger 1998), jotka niin ikään korostavat arvostelijan omaksumaa primäärituotannon ja vastaanoton väliin asettuvaa sillanrakentajan roolia. Primäärituotannolla viittaamme kirjailijoiden ja kustantajien toimintaan, joiden yhteistyön tuloksena eri tavoin ja eri suuntiin välitettäväksi tarkoitettu tuote, kirja, syntyy.

Käyttäjäarvostelijoiden muodostama Instagramin kirja-arvosteluyhteisö on eräänlainen käytäntöyhteisö (community of practice), jossa yhteisölle rakentuu yhteisessä vuorovaikutuksessa alustojen affordansseihin pohjautuen tietynlainen genreen sidottu tapa viestiä (Wenger 1998). Tarkastellessamme käyttäjälähtöisiä kirja-arvosteluja erityisenä alustatalouden ilmiönä kiinnostuksen kohteenamme on, miten alustat muovaavat käyttäjälähtöistä kirja-arvostelutoimintaa tarjoamalla tai mahdollistamalla arvostelijalle erilaisia funktionaalisia rooleja. Selvitämme siten, minkälaisissa funktionaalisissa rooleissa Instagramin kirjaarvostelijat toimivat ja mikä on näiden suhde institutionaaliseen, perinteiseen kirja-arvosteluun.

\section{Aineisto ja menetelmä}

Internetin yhteisöjä tutkittaessa haasteeksi nousee usein niiden volyymi: arkihavainnoin tai määrällisen erittelyn avulla on mahdotonta hahmottaa yhteisön rakennetta, sillä personoidut syötteet ja algoritmeihin perustuvat suosittelujärjestelmät tuottavat kuvan yhteisön rakenteesta jokaiselle käyttäjälle eri tavalla, ja julkaisujen suuren määrän takia edustavuutta on vaikea havaita, kun materiaalia ei ole mahdollista esimerkiksi koodata kokonaan manuaalisesti. Tämän vuoksi hyödynnämme otannan pohjana automaattisesti kerättyä suurta tietoaineistoa. 
Pohja-aineisto koostuu automaattisesti vuonna 2018 kerätyistä Instagram-julkaisuista, joissa on käytetty \#bookreview-aihetunnusta ( $n=631771$ ). Kuten sanottu, aineistoa on analysoitu aiemmissa artikkeleissa. Aikaisemmin aineistosta on analysoitu arvostelujulkaisuja (Jaakkola 2019, 2020a, 2020b) ja tuottajarooleja (Jaakkola ja Räisä 2019). Jaakkola (2019) on tarkastellut analyysissään myös suomenkielisiä \#kirjaarvostelu-julkaisuja. Tässä artikkelissa kavennamme aineiston osa-aineistoksi, joka kattaa aineistonkeruuhetkellä 40 maailmanlaajuisesti suosituinta kirja-arvostelijaa ja heidän 20 tuoreinta julkaisuaan. Suosittuus tarkoittaa tässä seuraajamäärää. Teemme havaintomme tästä osajoukosta, jonka oletamme edustavan arvostelutoiminnan "luovaa kärkeä", mutta samalla myös laajemmin koko yhteisön arvoja ja normeja. Sosiaalisen median genrehierarkiassa on nimittäin huomattu, että suosituimmat sisällöntuottajat ovat usein myös niitä, jotka asettavat lajityypin rajat ja uudistavat niitä, kun taas vähemmän suositut sisällöntuottajat matkivat näitä suosittuja tuottajia; genre siis harvoin uusiutuu marginaalissa (Himma-Kadakas ym. 2018).

Analyysimenetelmämme on laadullinen. Kuvaamme osa-aineistomme arvostelijoiden funktionaalisia rooleja pohjautuen Janssenin ja Verboordin (2015) kulttuuristen välittäjien tyypittelystä nousevaan neljään keskeiseen ulottuvuuteen. Kiinnitämme huomiota siihen, miten käyttäjäarvostelijat muovaavat näitä rooleja toisenlaisiksi Instagram-alustalla eli miten käyttäjäarvostelu poikkeaa arvostelugenreen perinteisesti liitetyistä ominaisuuksista. Nämä ovat viime kädessä johdettavissa kulttuurisen inter- ja intramediaation väliseen eroon, johon pureudumme analyysin lopuksi. Käsittelemme arvostelutoimintaa yleisellä tasolla emmekä nosta esiin yksittäisiä sisällöntuottajia, jotka eivät ole analyysissä tunnistettavissa.

Huomiomme keskipisteenä ovat arvostelujen mediaaliset ominaisuudet ja arvostelutoiminta alustoilla, ja rajaamme ulkopuolelle kysymyksen kirjallisuuden sisällöistä eli medioidun kulttuurikäsityksen (ks. Jaakkola 2021a, tulossa). Karkeasti sanottuna kulttuurikäsitys, mukaan lukien sen hierarkkinen luonne, joka kertoo kulttuuriyleisöjen mausta ja preferensseistä sekä kulttuurin kaanonista, on ollut taiteensosiologian keskeisin kysymys, kun taas mediatutkimuksen huomio on kiinnittynyt viestinnän luonteeseen ja siinä keskeistä on ollut valittu genre (ks. Jaakkola 2015). Se, mitkä kirjallisuuden lajit välittyvät alustatalouden arvosteluyhteisön kautta, on oma erillinen tutkimuskysymyksensä.

\section{Instagram arvostelun alustataloudessa}

Keskeisiä eli käyttäjämääriltään suurimpia kansainvälisiä alustoja, joilla käyttäjälähtöisiä kirja-arvosteluita esiintyy sellaisina kuin arvostelun edellä määrittelemme, ovat taulukossa 1 esitetyt digitaaliset palvelut. Kirja-arvioijille keskeisiä kirjallisuusspesifejä alustoja ovat Amazonin omistama vuonna 2006 perustettu lukupalvelu Goodreads sekä muut pienemmät vastaavat lukemisyhteisöt kuten LibraryThing, NetGalley, Bookself ja Reedsy Discovery. Suosituimmille kirja-alustoille, kuten Amazon-omisteiselle Goodreadsille, on syntynyt ja syntyy lukuisia pieniä vaihtoehtoisia foorumeita ja sovelluksia kuten BookSloth ja The Storygraph. Näiden lisäksi kirjoja arvostellaan myös kuluttajatuotteille luoduilla alustoilla (Amazon Customer Reviews, Google Review). Yhteisenä pääajatuksena näillä foorumeilla on ajatus julkisesta lukijasta (Steiner 2010): tavalliset inmiset seuraavat niillä lukuharrastustaan ja jakavat 
kokemuksensa muille saaden yhteisöltä tukea ja kannustusta. Foorumeilla siis osallistutaan "jaetun" tai "sosiaalisen lukemisen" (Fuller ja DeNel Rehnberg 2013, Herkman ja Vainikka 2012) käytäntöihin, joita on olemassa laaja kirjo oman virtuaalisen kirjahyllyn jakamisesta kirjavinkkaukseen ja aina kirjojen arvostelemiseen saakka.

Kirjallisuusspesifien alustojen lisäksi osa arvostelijoista hyödyntää myös sosiaalisen median yleisviestinnällisiä sovelluksia, joissa alusta ei rajoita käyttöä kirjateemaan. Suomessa on muutamia satoja kirjablogeja; esimerkiksi Mindmaxin ylläpitämällä Blogit.fi-alustalla oli vuoden 2021 alussa 300 blogia, joiden aihealueena oli kulttuuri. Lisäksi vuonna 2020 blogeissa oli julkaistu 6000 postausta, joiden täginä oli käytetty sanaa "kirja" ja 239 postauksessa oli käytetty tägiä "kirja-arvostelu". Kirjamaista arvostelutoimintaa on vakiintunut eniten YouTuben vlogeihin, BookTube- tai Kirjatube-yhteisöihin (Tomasena 2019).

Taulukko 1. Käyttäjälähtöisen kirjallisuusarvostelun vakiintuneimmat ja suosituimmat alustat.

\begin{tabular}{|c|c|c|c|c|}
\hline Alusta & Perustettu & Omistaja & Luonnehdinta & $\begin{array}{l}\text { Identiteetti- } \\
\text { yhteisö }\end{array}$ \\
\hline Blogit & $\begin{array}{l}\text { Blogger 1999, } \\
\text { WordPress } 2003\end{array}$ & $\begin{array}{l}\text { Blogger: Google, } \\
\text { WordPress: avoin } \\
\text { lähdekoodi }\end{array}$ & Julkaisualusta & $\begin{array}{l}\text { Kirjablogit, joita } \\
\text { itsenäisistä yhtei- } \\
\text { söihin (Blogit.fi, } \\
\text { Lily.fi) }\end{array}$ \\
\hline Amazon & $\begin{array}{l}1994 \\
\text { (Vine 2007) }\end{array}$ & Jeffrey Bezos ym. & $\begin{array}{l}\text { Johtava netti- } \\
\text { kirjakauppa }\end{array}$ & Asiakasarvostelut \\
\hline Goodreads & 2007 & Amazon & $\begin{array}{l}\text { Lukemiskulttuurin } \\
\text { alusta }\end{array}$ & Sosiaaliset lukijat \\
\hline LibraryThing & 2005 & $\begin{array}{l}\text { Tim Spalding, } \\
\text { AbeBooks, CIG }\end{array}$ & $\begin{array}{l}\text { Lukemiskulttuurin } \\
\text { alusta }\end{array}$ & Sosiaaliset lukijat \\
\hline NetGalley & 2008 & $\begin{array}{l}\text { Firebrand } \\
\text { Technologies, } \\
\text { Rosetta Solutions }\end{array}$ & $\begin{array}{l}\text { Lukemiskulttuurin } \\
\text { alusta }\end{array}$ & Sosiaaliset lukijat \\
\hline Instagram & 2010 & Facebook & $\begin{array}{l}\text { Mobiili- } \\
\text { kuvasovellus }\end{array}$ & Bookstagram \\
\hline YouTube & 2005 & Google & Videonjakoalusta & $\begin{array}{l}\text { BookTube, } \\
\text { Kirjatube }\end{array}$ \\
\hline $\begin{array}{l}\text { TikTok/ } \\
\text { Douyin }\end{array}$ & 2016 & ByteDance & $\begin{array}{l}\text { Mobiili- } \\
\text { videosovellus }\end{array}$ & $\begin{array}{l}\text { "Kirjamainen" } \\
\text { sisältö }\end{array}$ \\
\hline
\end{tabular}

Tarkastaltessa sitä, miten arvostelujen tuottamaa dataa synnytetään ja ohjaillaan siten, että alustantarjoaja saa siitä lisäarvoa, voidaan erottaa kahdenlaisia alustoja, joilla myös arvostelijuus rakentuu toisistaan poikkeavilla tavoilla. Kutsumme näitä alustatyyppejä arvosteluekosysteemin institutionaalisiksi alustoiksi ja ei-institutionaalisiksi alustoiksi (ks. 
myös Jaakkola 2021b, tulossa). Institutionaaliset alustat ovat arvostelemiselle omistettuja foorumeita, joita ohjaa institutionaalisen järjestyksen mukainen organisaatio, joka asettaa toiminnalle säännöt ja rajat, moderoi sisältöjä ja määrittelee käyttäjät lähtökohtaisesti amatööriarvostelijoiksi. Ei-institutionaaliset alustat ovat tyypillisesti yleisviestinnällisiä sosiaalisen median palveluja, jotka ovat avoimia teemaltaan ja käyttäjätyypiltään, mutta joihin syntyy sosiaalisen toiminnan rakenteistumisen seurauksena vakiintuneita yhteisöjä kuten Kirjatube tai Bookstagram. Näille alustoille on ominaista, toisin kuin institutionaalisen arvostelutoiminnan kehyksessä, että käyttäjät itse määrittävät aihepiirinsä rajat ja professionalisminsa asteen. Alustojen tematiikka ei siten ole rajattu pelkästään arvostelun genreen eikä tiettyyn kulttuurin lajiin. Alustoilla voi olla aktiivinen erilaisin kompetenssein, ja viestijöiden kompetenssiprofilit vaihtelevat maallikosta asiantuntijaan. Profiilien kirjo on suuri ja vaihtelee asteittain erilaisina muotoina, joita voidaan kutsua erilaisin hybridinimikkein, kuten "puoliammattilainen" tai "ammattimainen amatööri". Näin ollen pelkästään alustaa katsomalla ei voida määrittää, että arvostelijat ovat "amatöörejä".

Institutionaalisen amatörismin alustat on rakennettu tavalla, jossa datankeruu on systemaattista ja tietojen jatkohyödyntäminen strategisesti suunniteltua. Amatööriarvostelut erotetaan alustalla mahdollisesti esiintyvistä ammattilaisarvioista, ja arvostelijat voidaan listata automaattisesti järjestykseen heidän aktiivisuutensa ja suosittuudensa mukaan. Käyttäjien on mahdollista arvioida julkaistuja arvosteluja sen mukaan, onko niistä heille apua vai ei, joten julkaistuista arvosteluista saadaan hierarkioita sen mukaan, miten hyödyllisiksi ne on koettu. Näiden ominaisuuksien perusteella esimerkiksi Amazon voi hyväksyä kaikkein tuotteliaimmat ja "luotettavimmat" arvostelijat Vine-ohjelmaan, jossa yritykset maksavat Amazonille saadakseen tuotteita arvioitaviksi. Ei-institutionaalisilla alustoilla dataa ei kerätä suoraan arvosteluista, vaan arvosteleminen sulautuu muuhun viestintään. Dataa voidaan toki kerätä esimerkiksi aihetunnisteiden ja kategorioiden perusteella, mutta datan hyödyntämisen rakenteet eivät ole yhtä suoralinjaisia eivätkä kirjakulttuurin erityisyyteen liittyviä kuin institutionaalisen arvostelun alustoilla. Kaupalliset yhteistyösuhteet syntyvät myös arvostelijakohtaisesti, tai arvostelijat voivat olla jäseniä alustojen ulkopuolisissa yhteisöissä, joista he saavat tuotteita arvosteltaviksi.

Vuonna 2010 perustettu Instagram on ei-institutionaalinen arvostelualusta, jonka ensisijainen viestintätapa on visuaalinen. Muille visuaalisille alustoille, kuten Pinterestiin, ei ole syntynyt yhtä vahvaa arvostelukulttuuria, vaikka niissäkin kirjamaisuuden kulttuuria on vaalittu (Rodnek 2019). Instagram on ollut vuodesta 2012 Facebookin omistama mobiilisovellus, jota on mahdollista seurata rajoitetusti myös nettiselaimen avulla. Sovellus perustuu kännykkäkuvien jakamiseen, mutta kuvien oheen on mahdollista lisätä myös maksimissaan 2200 merkin pituinen (kuva)teksti. Yleisteemaisena visuaalisena alustana Instagramista on tullut kasvualusta monelle erilaiselle alakulttuurille (Leaver ym. 2020), joissa visuaalinen tyyli on tärkeä (Manovich 2017), mutta juuri kirjakulttuurista on tullut maailmanlaajuisesti suosittu ja legitiimi teema tällä alustalla.

Vuoden 2018 loppuun mennessä Instagramissa oli 26 miljoonaa Bookstagram-aihetunnisteella varustettua julkaisua, ja syksyyn 2020 mennessä niitä oli jo yli 50 miljoonaa. Instagramin kirjakulttuurissa on myös käytössä lukuisia erilaisia Bookstagram-termiin liittyviä johdannaisia, kuten \#bookstagrammer, \#mybookstagram tai \#indianbookstagram. Yhteisöllä on myös paikallisia muotoja, kuten suomalainen Kirjagram, johon suoraan liittyviä 
\#kirjagram-julkaisuja oli lokakuussa 2020 vajaat 76 ooo kappaletta. Lontoon kirjamessuilla on vuodesta 2018 valittu vuoden "bookstagrammeri". Kirjamainen estetiikka tarkoittaa shelfieiden (kirjahyllykuvien, vrt. selfie) esittelyä, kirjankansien latomista asetelmiksi ja kirjoihin liittyvän tunnelman luomista erilaisten valintojen kautta. Bookstagramia voi väljästi luonnehtia kirjakulttuurin ja kirjaan liittyvien elämäntyylien yhteisöksi.

\section{Arvostelijoiden funktionaaliset roolit}

Käyttäjäarvostelijoiden on tehtävä itsensä hyödylliseksi yleisöilleen - saadakseen seuraajia ja taatakseen toimintansa jatkuvuuden - mutta samalla he tekevät itsensä hyödyllisiksi alustantarjoajille, jotka hyötyvät kasvavista käyttäjämääristä ja kasvavasta määrästä dataa. Siksi on kysyttävä, miten käyttäjäarvostelijat tekevät itsensä hyödyllisiksi yleisöilleen eli minkälaisia vakiintuneita viestintäkäytäntöjä alustalla on. Kuten aiemmin olemme kuvanneet, viestintäkäytännöt taas muuntuvat sosiaalisen yhteisön normeiksi tarjolla oleviin affordansseihin pohjautuen. Arvostelu on genre, joka on ollut olemassa jo ennen Instagramin syntyä. Kuten aiemmin on todettu, arvostelulla on tiettyjä perusperiaatteita, kuten odotukset uusien taiteen tuotteiden esittelemisestä ja arvottamisesta, arvostelijan toiminnan tietoisuudesta (arvostelijaidentiteetti) ja pitkäkestoisuudesta (arvostelijaprofiili). Kiinnostavaa on siten se, miten arvostelun genre mukautuu alustan vaatimuksiin ja rajoituksiin, sekä minkälaisia jännitteitä genren ja alustan vaatimusten välille syntyy.

Genrenormit tiivistyvät pitkälti arvostelijoiden funktionaalisiin rooleihin, joita arvostelijat noudattavat. Janssen ja Verboord (2015) erottavat perinteisten kulttuuristen välittäjien keskuudessa viisi eri funktionaalista genreen kuuluvaa roolia (ks. myös Orlik 2016). Kulttuuriset välittäjät esiintyvät heidän mukaansa seuraavissa rooleissa, joista arvottaja on arvostelijan muista sisällöntuottajista erottava eli distinktiivinen rooli, eräänlainen avainrooli:

- Portinvartija (gatekeeper): arvostelijat määrittävät, mitkä teokset saavat huomiota arvostelujulkisuudessa ja minkälaista on hyvä maku.

- Arvottaja (evaluator/meaning-maker): arvostelijat kuvaavat, tulkitsevat ja arvioivat valittuja teoksia määrittäen niiden arvoa ja luoden merkityksiä.

- Sillanrakentaja (connector): arvostelijat luovat yhteyksiä primäärituotannon ja yleisön välille.

- Myyjä/markkinoija (seller/marketer): arvostelijat asettuvat promoottoreiksi tuotteelle, jota arvioivat.

- Jakelija (distributor): arvostelijat jakavat arvosteluaan digitaalisesti.

Portinvartijuus liittyy välittäjäasemaan kirjallisuuskentän ja yleisön välillä. Se liittyy vahvasti arvottajan rooliin, jossa arvostelija asettuu primäärituotannon ja yleisöjen väliin pyrkien lukemaan teosta kriittisesti yleisölleen sitä tulkiten. Myyjän rooli kuvaa arvostelijan suhdetta primäärituotantoon, kun taas verkostoituja ja jakelija liittyvät arvostelijan yleisösuhteeseen. Tämän perusteella voi sanoa, että alustoitunutta arvostelutoimintaa voi kuvata ja ymmärtää seuraavien arvostelutoiminnan ydinalueiden avulla: 
- Sisällöntuottajuuspositiot: minkälaisiin tuottajapositioihin käyttäjäarvostelijat itsensä asemoivat, minkälainen on heidän ammatti-identiteettiä vastaava tuottaja-asemansa?

- Sisällöt ja ilmaisutavat: minkälaisia sisältöjä alustan affordanssijärjestelmät tuottavat?

- Tuotantokontekstit: minkälaisen suhteen alustaan ja primäärituotantoon käyttäjäarvostelijat luovat?

- Yleisösuhde: minkälaisia suhteita yleisöön - tai minkälaisia yleisöjä - käyttäjäarvostelijat luovat?

Kiinnostava kysymys on, miten edellä mainitut institutionaalisen arvostelun ominaisuudet sopivat ja sovitetaan käyttäjäarvosteluissa yhteen kaupallisten, arkikulttuuristen ja verkostomaisten alustojen kanssa. Jokaiseen keskeiseen ulottuvuuteen liittyy erilaisia jännitteitä ja problematiikkaa suhteessa arvostelun perinteisiin tavoitteisiin ja toimintamuotoihin sekä alustan toivottuihin käyttötapoihin. Affordansseja siis käytetään "väärin" - luovasti tai manipuloiden - jotta voitaisiin saavuttaa arvostelijoiden arvostamia tavoitteita. Pureudumme seuraavaksi näihin neljään ydinalueeseen aineistosta nousevien havaintojen perusteella. Laadullisessa analyysissä kysymme, miten arvostelu(genre)n ja alustan väliset jännitteet käytännössä toimivat. Pyrimme näin tarkastelemaan mahdollisia ongelma- ja kitkakohtia, joita alustanomaisuus aiheuttaa nimenomaan arvostelutoiminnalle ja sen oletetuille tavoitteille.

\section{Tuottajapositiot}

Käyttäjäarvostelija on julkinen lukija: valittuaan ja luettuaan tietyn teoksen hän tekee tietoisen valinnan jakaakseen kokemuksensa muille oletettavasti samasta aihepiiristä kiinnostuneille lukijoille (ks. myös Steiner 2020). Käyttäjäarvostelijat ovatkin henkisesti hyvin tiiviisti sitoutuneita lukija-, fani- ja muihin vastaanottoyhteisöihin. Tämä näkyy heidän tavoissaan puhua itsestään ja esittää itseään arvostelijana. He pyrkivät viestinnässään ensinnäkin usein puhuttelemaan muita käyttäjiä ja korostamaan olevansa tavallisia lukijoita eivätkä halua erottautua muusta lukijajoukosta, vaikka käytännössä tulevatkin korotetuksi enemmän tai vähemmän ohjailevaan asemaan julkisten puheenvuorojensa takia. Kirja-arvostelijat pyrkivät tyypillisesti myös korostamaan intohimoista suhdettaan kirjallisuuteen ja lukemiseen ja kutsuvat itseään esimerkiksi kirjatoukiksi, kirjojen ystäviksi, kirjanörteiksi tai kirjojen hamstraajiksi. "Kirjarakkaus" on kuin pakkomielle tai sairaus, jota vastaan on turhaa taistella (ks. myös Mäkinen 2014). Myös perinteiset arvostelijat korostavat intohimoista suhdettaan taiteenalaansa, mutta he pyrkivät, hieman ristiriitaisesti, etäännyttämään itsensä arvosteltavista kohteista; he noudattavat teksteissään emotionaalisuuden strategista rituaalia, jossa tunteelliset argumentit pyritään perustamaan rationaalisesti legitimoiden ne asiantuntijamielipiteenä (Wahl-jorgensen 2012).

Instagram-arvostelijat eivät ole samanlaisessa portinvartija-asemassa kuin institutionaaliset arvostelijat. Perinteinen ammatillinen kirjallisuusarvostelija saa arvosteltavakseen teoksia, jotka toimitus hyväksynyt, usein sen perusteella, että ne kuuluvat kaanoniin ja luokitellaan siten kulttuuris-yhteiskunnallisesti relevanteiksi teoksiksi (Janssen 1997). Käyttäjäarvostelijat eivät pyri kattavuuteen suhteessa johonkin tiettyyn kirjallisuudenalaan tai genreen, kuten perinteiset kriitikot, joiden julkisena tehtävänä on seurata jotain tiettyä taiteenalaa ja pyrkiä siitä journalistiseen edustavuuteen. Käyttäjäarvostelijat sen sijaan tyypillisesti koros- 
tavat sitä, että he kertovat kirjoista, joita haluavat lukea; kirjavalinnat kuvastavat vain ja ainoastaan heidän omaa makuaan. Tiiviisti vuorovaikutuksessa oman yhteisönsä kanssa toimivat käyttäjät saavat monet arvosteluvinkeistä toisilta käyttäjiltä, mikä kytkee heitä yhä enemmän siihen yhteisöön, jossa he toimivat. Usein valintoihin vaikuttaa myös se, mitä kirjoja yksinkertaisesti on milloinkin saatavilla eli mitä kustantajat ja agentit lähettävät arvostelijoille ilmaiseksi.

Käyttäjäarvostelijan on siten mahdollista valita teoksia arvosteltavakseen kaanonista piittaamatta jopa varsin instrumentaalisesti, esimerkiksi siihen tukeutuen, missä teoksissa on paras potentiaali näkyvyyden kasvattamiseen ja kaupallisten yhteistyösuhteiden luomiseen. ACR- ja affiliaatiojärjestelmät pyrkivät tarjoamaan käyttäjäarvostelijoille paitsi ansaintamyös sisällöntuotantomahdollisuuksia luomalla konkreettisesti edellytykset tiettyjen teosten saatavuuteen. Hieman provosoivasti voidaan sanoa, että oman mikromedian menestys on käyttäjälle tärkeämpää kuin demokraattinen palvelutehtävä hyvän maun tai sisällön laadun osoittajana. Siirtymä tuotteiden arvostelijasta niiden promoottoriksi - kirjakriitikosta kirjakulttuurin sosiaaliseksi vaikuttajaksi - on asteittainen ja hienovarainen. Autenttisuuden tunnun on havaittu edistävän vaikuttajien ja sponsoroivien brändien vaikuttavuutta, ja sisällöntuottajat myös hyödyntävät strategisesti autenttisuutta sisältönsä vaikuttavuuden kasvattamiseksi (Luoma-aho ym. 2019). Käyttäjäarvosteluissa, joissa keskeisintä on kertoa, että käyttäjä on lukenut tai juuri lukemassa tiettyä teosta, ja näyttää teoksen olemassaolo, arvostelusta jää puuttumaan arvostelua keskeisesti määrittävä arvottava elementti, teoksen sisällön arvioiminen ja suhteuttaminen, jolloin se jää pelkäksi suositukseksi (endorsement) tai kuvailevaksi tuote-esittelyksi. Visuaalisuus ja tekstin lyhyys Instagramissa ohjaavat käyttäjää sisällöntuotannossa tähän suuntaan.

Käyttäjäarvostelijoille on ominaista sujuva liikehdintä eri alustojen välillä, mikä on erityisen merkillepantavaa juuri Instagramissa. Van Dijckin (2014) sanoin kyse on "kitkattomasta jakamisesta". Vaikka Instagramissa julkaistaan myös paljon pelkästään tälle alustalle tuotettuja kirja-arvosteluja ja moni Instagram-arvostelija kuvaa esimerkiksi blogissaan tai biossaan ryhtyneensä kirja-arvostelijaksi juuri Instagramissa viestinnän suhteellisen nopeuden ja helppouden takia, kuvavetoisena sovelluksena Instagram ei ole välttämättä ensisijainen vaihtoehto arvosteluille, jotka vaativat usein enemmän tilaa kuin Instagramin tarjoaman tekstikentän verran. Näin ollen monilla kirja-arvostelijoilla on käytössä myös profiili jossain lukijapalvelussa (esim. Goodreads) tai oma blogi tai vlogi. Instagram toimii tällöin enemmänkin yleisöjen tavoittamisen ja näkyvyyden lisäämisen välineenä, mikä lisää promootionäkökulman merkitystä. Toisaalta tämän takia käyttäjäarvostelijat kehittävät itselleen jonkinlaista alustojenvälistä toimijuutta, jossa on tärkeää havaita kunkin alustan tarjoamat affordanssit ja hyödyntää niitä parhaalla mahdollisella tavalla. Omaa sisältöä versioidaan eri alustoille affordansseihin sopeutuen.

Käyttäjäarvostelijoista tulee Instagramissa myös vaikuttajia. Kirjan arvottaminen ei ole käyttäjäarvosteluissa elintärkeässä osassa, joten he eivät välttämättä ole mielipidevaikuttajia, vaan tyyli- ja elämäntyylivaikuttajia. Monet käyttäjäarvostelijat asettautuvat lukevan elämäntavan edustajiksi ja pitävät lukemista terveellisen elämäntavan merkkinä. He kokevat näin ollen olevansa jonkinlaisia lukemisenedistäjiä ja kirjakampanjoijia, jotka oman esimerkin voimalla edistävät jotain hyvää yhteiskunnallista asiaa. Kyseessä ei niinkään ole sivistys tai laadukkaan kulttuurin arvostaminen, vaan merkittävää on olla aktiivinen, pitää 
huolta itsestään mentaalisesti ja edistää siten omaa mielenterveyttään lukemalla. Tällaisen self care -näkökulman ohessa osa käyttäjäarvostelijoista asettuu myös kaupallisiksi vaikuttajiksi, jotka ovat lähempänä vaikuttajien (social influencers) roolia vaikuttajamarkkinoinnin kontekstissa. Vaikuttajat ilmoittavat kirjojen ostopaikat ja hintatiedot sekä omaksuvat markkinoinnin estetiikalle tunnusomaisia piirteitä. He ovat myös avoimia monille kaupallisille yhteistöille. Kirjankaupustelija-arvostelijat suostuttelevat vastaanottajaa ajattelemaan kirjaa ennen kaikkea myytävänä ja ostettavana esineenä, jolloin kirja osallistuu alustataloudelle tyypilliseen markkinavetoiseen diskurssiin. Instagramissa kirjaa kaupittelevat näyttävät kuitenkin jäävän alakynteen, ja \#bookreview-aihetunnistetta käyttäviä kirjakauppiaita tai kirjailijoita on vaikea pitää määritelmällisesti arvostelijoina, joten hallitseva diskurssi ja itseymmärrys Instagramissa on kuitenkin epäkaupallinen.

Yleisesti voidaan todeta, että välittäjäasemassa käyttäjäarvostelijat eivät pyri toimimaan primäärituotantoon kytkeytyvänä ammattivälittäjänä, vaan heidän toimintansa nousee harrastajayhteisön intresseistä käsin ja he pyrkivät enemmänkin toimimaan osana tuota yhteisöä. Institutionaalisen arvostelun edustavuusvaatimuksen korvaa autenttisuuden määre (arvostelija on "kuin kuka tahansa"), ja arvostelija asettuu vaikuttajaksi. Vaikuttaja-asemia on karkeasti kahdenlaisia: kaupallinen vaikuttaja ("influensseri") ja demokraattis-esteettinen vaikuttaja (lukemisenedistäjä).

\section{Sisällöt ja ilmaisutavat}

Instagram on kirja-arvostelu- ja kirjakulttuurissa erityinen alusta, sillä sen kuvavetoisuus erottaa sen muista kirjamaisuuden alustoista. Siinä missä visuaalisuutta painottuvista alustoista esimerkiksi YouTube mahdollistaa suullisen viestinnän retoriikan ja TikTokissa korostuvat kehollisuus ja liike, Instagramissa visuaalinen estetiikka nousee väistämättä keskiöön, mikä muodostaa huomattavan kontrastin arvostelun korostetun tekstikeskeiseen perinteeseen. Arvostelukulttuuri, etenkin kirja-arvostelukulttuuri, on toisin sanoen luonteeltaan erityisen grafosentrinen, ja ajatuksena on, että arvostelija argumentoi näkemyksensä lukijoilleen (Blank 2007). Arvostelun kuvittaminen tai arvostelun sanoman visualisointi ei ole ollut vakiintunut käytäntö millään muulla aikaisemmalla kirjafoorumilla eikä varsinkaan institutionaalisessa arvostelukulttuurissa, jossa arvosteluiden kuvittaminen on ollut jopa satunnaista. Instagram-arvostelujen sisältöjä tarkasteltaessa on huomiota kiinnitettävä visuaalisen esittämisen eri käytäntöihin.

Instagramin kirjamaisuuden estetiikka perustuu pitkälti kirjan kuvaamiseen materiaalisena artefaktina, esineenä, joka on sijoitettu johonkin ympäristöön mutta joka usein nousee käyttöesineestä visuaaliseksi silmänruoaksi. Kirjojen asetteleminen kuvaan muistuttaa somistamista. Kauneusvaikutelmaa tavoitellaan runsaudella tai pelkistetyn tyylikkäillä kirjaasetelmilla, mikä toistettuna synnyttää tunnistettavaa kerrontaa, alustatalouden narratiivia, joka puhuttelee ja saa aikaan vastakaikua muissa kirja-arvostelijoissa. Kuvassa saattaa olla vain yksi kirja tai kirjoja hyödynnetään asetelmina. Kirja-arvostelun kuvauspaikkojen valikoimaa voi luonnehtia niukaksi: olipa kirjat kuvattu sisällä tai ulkona, keskiössä on miltei aina kirjan kansi. Kuvat ovat tyypillisesti värein, viivoin ja eri muodoin kehystettyjä kirjakoosteita, joissa ympäristöä hyödynnetään vain satunnaisesti niin, että kuvissa näkyy jokin fyysinen elementti, kuten pöydän reuna, kukka tai taustakangas. Yhdestä kuvasta löysimme 
yhteensä kaksikymmentä erilaista esinettä; kuvakulma oli ylhäältä niin, että esineet näkyvät tarkasti. Nämä lavasteet toimivat indeksisinä lisukkeina, jotka luovat mielikuvia lukemisen intiimiydestä. Kahvi- tai teemukit, torkkupeiton reunat, äänikirjan kuulokkeet ja kirjan vierelle sijoitetut esineet, joilla on todennäköisesti jokin henkilökohtainen merkitys omistajalleen, kielivät lukemisen yksityisyydestä ja yksilöllisestä nautinnollisuudesta. Sofistikoitunut visuaalisuus syntyy tarkasta sommittelusta, harkitusta valaistuksesta, värimaailmasta ja rekvisiitasta. Kirjasomistajat ovat kuin kirjakulttuurin aatelisia, joille on tärkeää synnyttää vaikutelmaa ylenpalttisuudesta: huolitellut kirjakuvat suostuttelevat vastaanottajaa ajattelemaan kuviin investoitua aikaa. He hyödyntävät yksityisen ja julkisen rajan hälventymisestä syntyvää jännitettä ja houkuttavuutta. Ympäristö on kaikkein yleisemmin koti ja kodin yksityinen piiri. Toinen, joskaan ei yhtä yleinen, paikka on jokin julkinen tila: katu, kirjasto, ranta tai luonto.

Toinen tapa kuvata kirjaa on somistamiselle vastakkainen ja ad hoc -tyylinen: kirja esitetään jossain kontekstissa ikään kuin puolihuolimattomasti kuvattuna, ei-aseteltuna, miltei paikalleen unohdettuna. Tällöinkään itse lukijat eivät ole kuvissa pääosassa, mikä on päinvastaista Instagramin selfie-kulttuurille. Shelfie-kulttuurin voikin sanoa olevan eskapismia ei pelkästään siinä mielessä, jollaisena eskapismi lukemiseen liitetään, vaan myös kääntymisenä poispäin Instagramin kehollisesta, ulkonäkökeskeisestä normittavuudesta (Deeb-Swihart ym. 2017). Sisältönäkökulmasta voidaan sanoa, että tärkeää kuvavetoisessa viestinnässä on oikeanlaisen tunnelman luominen (ks. Kolehmainen ja Mäkinen 2019). Tunnelman luomisen tarkoituksena on ylistää lukemisen ihanuutta ja vahvistaa lukijayhteisön rakkautta lukemiseen.

Tekstisisällöt ovat lyhyehköjä johtuen alustan tarjoamista rajoitetuista kirjoitusaffordansseista: tekstille on varattu suhteellisen pieni tila, kännykän ruudulla tekstit on kirjoitettava sormin, mikä saattaa rajoittaa käyttäjien halukkuutta kirjoittaa pitkiä tekstejä, ja koko tekstiä kutsutaan kuvatekstiksi. Teksti on alustan affordanssihierarkiassa siten kuvalle selvästi alisteisessa asemassa, ja tavallaan kirja-arvostelijat käyttävät sovellusta jopa vastakarvaan yrittäessään kirjoittaa toisinaan varsin pitkiäkin selostuksia kirjoista ja lukukokemuksestaan. Arvottamisen sijaan käyttäjäarvostelijat pyrkivät avaamaan nimenomaan lukukokemustaan ja laajemmin lukemisharrastustaan. Kirjan sijoittaminen johonkin kontekstiin on tärkeää, mutta konteksti on harvoin primäärituotannon konteksti. Kirjoja ei niinkään pyritä sijoittamaan kirjoittajan aiempaan tuotantoon tai kirjalliseen perinteeseen vaan omaan lukuhistoriaan tai lukemistavoitteeseen - monet käyttäjäarvostelijat listaavat profiilitekstissään vuositavoitteensa ja pyrkivät siten tiettyyn määrälliseen lukutavoitteeseen - tai lukutilanteeseen ja tilanteessa heränneisiin reaktioihin.

\section{Tuotantokontekstit}

Instagram-viestinnän on havaittu painottavan viestijöiden yksityisiä, maallisia, tavanomaisia ja intiimejä ulottuvuuksia; esimerkiksi koti on yksi keskeinen paikka, jossa kuvia otetaan (Barbour ja Heise 2019). Myös kirja-arvosteluissa korostuvat kodin, perheen ja yksityispiirin teemat, kuten edellä kuvatuista sisällöistä on havaittavissa. Keskiössä on kirjan käyttö: lukukokemus, kirjan sijoittuminen materiaalisena artefaktina, esimerkiksi sisustusesineenä, osaksi omaa kotia tai esteettis-visuaalista makua.

Kirjan käyttökontekstit - jotka Instagramin kaltaisella alustalla toimivat myös eräänlaisina näyttökonteksteina eli visualisoitavina tiloina - ovat hyvin erilaiset kuin kirja-arvostelun insti- 
tutionaalisessa perinteessä. Konteksteista, joissa kirja esitetään Instagramin arvostelujulkaisuissa, kolme dominoivaa ovat: 1) oma lukuharrastus ja elämäntyyli, 2) yksilöllinen kehittyminen ja oma-aika, 3) koti ja oman intiimin sfäärin avaaminen. Koti ja sisustus liittyvät keskeisesti visuaalisiin ilmaisutapoihin, joista oli puhetta edellisessä jaksossa, joten tarkastelemme tässä kahta muuta tuotantokontekstia.

Institutionaalisessa, perinteisessä kirja-arviossa teoksen vastaanottokonteksti on tyypillisesti häivytetty; arvostelija harvoin näyttää ulkotaiteellisia asioita, kuten minkämakuista teetä on tullut juoneeksi kirjaa lukiessaan ja minkänäköisestä kupista, tai kertoo, minkälaisessa tilanteessa teos on vastaanotettu. Kirjan vastaanottokonteksti on primäärituotannon tarjoama esteettis-historiallinen konteksti, joka on intellektuaalinen, osa aate- ja kirjallisuushistoriaa tai kritiikkiä eikä juurikaan materiaalinen (Lehtonen 2001). Perinteisen kirjallisuusinstituution tuottama kirja-arvostelu, joka on tyypillisesti julkaistu kirjoitettuna tekstinä päivä- tai aikakauslehdessä, on siten ollut kontekstiltaan varsin vakioitu genre, jossa tekijöiden itsensä vaaliman diskurssin mukaan sisältö ratkaisee eli teksti voidaan periaatteessa jopa luoda tietämättä siitä, minkälaiseen julkaisuyhteyteen se on tulossa, sillä se on osa tietynlaista retorista perinnettä. Teksti on toisin sanoen perustunut arvostelijan argumentointiin ja kolmiosaiseen mallin, jossa kuvailu, tulkinta ja arvottaminen ovat keskeisessä osassa (Waugh 2006). Arvostelija on näkymätön, kasvoton ja ei-kehollinen hahmo, jonka tärkein attribuutti on hänen maineeseensa perustuva profiili.

Instagram-arvosteluissa oman lukuharrastuksen esittäminen on usein visuaalis-mentaalisen ikkunan avaamista lukukokemukseen: katso, tämän kirjan päätin lukea, tältä se tuntui, tältä se näytti, tältä tuntuu nyt. Arvosteluja saatetaan kirjoittaa pitkin matkaa, ei pelkästään lukuprosessin päätyttyä. Joillekin arvostelutoiminta linkittyy oman lukemissuorituksen seuraamiseen lähes urheilusuorituksen tavoin ja luettujen kirjojen esittely on osa oman harrastuksen dokumentointia, seurantaa, esittelyä ja jakamista muille. Tällaista lähestymistapaa tukee vahvasti sosiaalisen lukemisen palveluiden kulttuuri, jossa lukemiselle on tapana listata määrällisiä tavoitteita ja lukijoiden käytäntönä on "katalogisoida" luettuja ja lukuun valittuja kirjoja. Lukemisen tavoitteellisuudella ja lukumaratoneilla on myös yhteyksiä itsen mittaamiseen, jossa "määrällistetystä minästä", tässä tapauksesta itsestä kulttuurisena tai lukevana kansalaisena, tulee tarkkailun kohde (Lupton 2016). Toisten arvostelutoimintaa taas tukevat erilaiset arvosteluun kannustavat yhteisölliset rakenteet, kuten lukemisenedistämiskampanjat (esim. kirjastojen lukuhaasteet) tai yhdessälukutoiminnot ("buddy reads" eli kaverilukeminen Goodreadsissa).

Itsen esittäminen lukevana kansalaisena saa myös itsestään huolehtimisen, terveellisen elämäntavan ja itsensä kehittämisen ulottuvuuksia. Itsestään huolehtiminen (self care) asettuu oman ajan ottamisen oikeutukseksi, ja lukemisen kuvaillaan julkaisuissa monesti olevan itsensä auttamisen ja kehittämisen muoto, eräänlainen self help -metodi. Arvostelujen tuottaminen on paitsi itsen, myös muiden kehittämisen muoto: jakamalla omaa harrastuneisuuttaan voi asettua muiden esikuvaksi ja inspiroida yhteisöä lukemaan, ja yhteisön jäsenet voivat siten vahvistaa toistensa motivaatiota ja ruokkia mielenkiintoa rakentavaa harrastusta kohtaan.

Kaikki edellä kuvatut kontekstit ovat hyvin minäkeskeisiä, eivät esimerkiksi teoskeskeisiä. Tämä käy hyvin yksiin jo blogikulttuurista tunnetun ajatuksen kanssa, että bloggaaminen on päiväkirjamainen, minäkeskeinen dokumentoinnin muoto (ks. esim. Steiner 2010). Kirja-arvostelua, kuten kulttuurijournalismiin kytkeytyviä arvosteluja yleensäkin, on kui- 
tenkin perinteisesti pidetty kaupallisuutta vieroksuvana genrenä, joka perustuu arvostelijan integriteettiin ja arvostelun riippumattomuuteen. Mediaorganisaatio onkin valitessaan arvostelijat ja maksaessaan heille palkan taannut sen, ettei arvostelijan ole itse tarvinnut keksiä ansaintalogiikkaansa. Aineistosta on nähtävissä, että arkinen konteksti kuitenkin helpottaa käyttäjäarvostelijoita artikuloimaan kirjan helpommin myös kulutushyödykkeeksi ja kaupalliseksi tavaraksi.

Alustojen monetisaatio eli alustaan sisäänrakennetut voitontavoittelun mekanismit johtavat siihen, että arvostelijoille ainakin periaatteessa tarjoutuu mahdollisuus muuttaa toimintansa jollain tavalla kannattavaksi saamalla siitä myös jotain aineellista hyödykettä. Edellä oli puhe alustakapitalismin toiminnasta, jolle myös käyttäjäarvostelijat alistuvat, joten keskitymme tässä erityisesti käyttäjäarvostelijoiden itse tavoittelemiin monetisaation tapoihin, kuten mahdollisuuksiin saada erilaisten yhteistyösuhteiden kautta itselleen kirjoja tai muita tuotteita tai yksinkertaisesti tuloja eli rahallista palkkaa tekemästään työstä. On arvostelijoita, jotka pyrkivät henkilökohtaiseen hyödyntavoitteluun luomalla yhteistyökumppanuuksia esimerkiksi äänikirjoja myyvän yhtiön kanssa. Kirja-arvostelun aihetunnusta käyttävät myös kirjoja avoimesti markkinoivat ja myyvät käyttäjät, jotka ovat esimerkiksi kirjailijoita tai kirjakauppiaita.

Alustoilla toimivat yksilöt tekevät työtä lähtökohtaisesti ilman rahallista korvausta. Tämä tekee käyttäjäarvostelijasta periaatteessa vapaan toimimaan kuten haluaa, mutta mitä pidempikestoiseksi, tavoitteellisemmaksi ja laajamittaisemmaksi arvostelutoiminta rakenteistuu, sitä suurempi todennäköisyys on, että käyttäjäarvostelija alkaa etsiä erilaisia rahoituskeinoja toimintansa jatkuvuuden turvaamiseksi. Verrattuna moniin muihin alustaviestinnän lajityyppeihin kirja-arvostelut ovat luonteeltaan kuitenkin varsin epäkaupallisia. Tämä voi osaksi johtua siitä, että kulttuurisen toiminnan logiikka pyrkii näkemään rahallisen ja materiaalisen toiminnan tavoittelun epätoivottavana etsien autonomiaa heteronomian sijaan. Toiseksi kirjanystävien voi olla vaikea löytää suoraan sponsoreita, sillä vain harva käyttäjäarvostelija haalii massayleisöjä ja eivätkä nämä yleisöt ole kulutustottumuksiltaan kovin materiaalisesti suuntautuneita.

Tiivistäen voidaan todeta, että alustatalouden erilaiset monetisaation periaatteet pakottavat käyttäjäarvostelijat yksityisyrittäjämäiseen asemaan "mikromedian" pyörittäjiksi (Manovich 2000). Heidän on oltava suoraan tekemisissä alustan kaupallisen logiikan sekä kirja- ja kustannusalan taloudellisten sidonnaisuuksien kanssa. Perinteinen arvostelija on mediaorganisaation pyörittämässä instituutiojärjestyksessä erotettu tästä heteronomisesta ulottuvuudesta.

\section{Yleisösuhde}

Perinteisten joukkotiedotusvälineiden arvostelijoille tarjoamaa yleisösuhdetta voi luonnehtia melko etäiseksi verrattuna käyttäjäarvostelijoille alustalla rakentuvaan yleisösuhteeseen. Perinteiseen institutionaaliseen arvosteluun liittyykin useita ulottuvuuksia, jotka ovat rakentaneet etäisyyttä sen yleisöihin. Ensinnäkin arvostelu on ollut pitkään sidoksissa korkeakulttuurin tuotteisiin ja niihin liittyviin diskursseihin, vaikka myös populaarikulttuurin tuotteita on säännöllisesti arvosteltu, mutta se on kaikissa institutionaalisissa muodoissaan ollut vahvasti kytkeytyneenä primäärituotannon tavoitteisiin, diskursseihin ja käytänteisiin. Arvosteli- 
jan on täytynyt syvällisesti ymmärtää näitä osatakseen kuvata, tulkita, kontekstualisoida ja olla kriittinen (Orlik 2016). Tämä on johtanut kritiikkiin arvostelun sisäänrakennetusta elitismistä. On kritisoitu, että sen sijaan, että arvostelijat olisivat rakentaneet helposti lähestyttäviä väyliä uusien kulttuurituotteiden lähestymiseen, he ovat soveltaneet eliittisen taideyleisön puhetapoja ja halunneet näin näyttää osallisuutensa taide- ja kulttuuriyleisöjen ja vallan ytimessä (Janssen 1997). Toiseksi arvostelu on ollut muodoltaan ja moodiltaan pitkälti yksisuuntainen monologi, jonka tarkoituksena on, että arvostelija, hyvän maun edustajana ja taiteenlajin laadun vaalijana, lausuu oman perustellun mielipiteensä ja kertoo kokemuksestaan taiteen parissa (Blank 2007). Kolmanneksi arvostelijoiden hyödyntämä emotionaalisen objektivoinnin strateginen rituaali (Wahl-Jorgensen 2012) on pyrkinyt rakentamaan ammattimaisen viileän vaikutelman arvostelijasta, joka innostuessaankin kykenee argumentoimaan tunteistaan järjen avulla eikä luota primitiivisiin ensireaktioihin.

Käyttäjäarvostelijat ovat institutionaaliseen arvostelun genreen verrattuna lähellä yleisöjään. Arvostelija näkee halutessaan joka ikisen rekisteröityneen seuraajansa ja voi vastavuoroisesti seurata heidän tuottamiaan sisältöjä. Seuraajilla on myös suora mahdollisuus kommentoida ja kysyä. Alustoilla arvostelijan monopoliasema suhteellistuu, sillä viestintä on monensuuntaista ja vastavuoroista: aiheita poimitaan yhteisöstä, arvosteluista tykätään ja niitä kommentoidaan eli niiden kylkeen kertyy julkista palautetta, arvostelut asettuvat vuoropuheluun ristiinviittausten, linkkien ja yhteistyökuvioiden avulla, ja keskustelu jatkuu. Arvostelijat ovat kokemuksellisesti osa yleisöjä eivätkä pyri erontekoihin näistä yleisöistään kuten institutionaaliset arvostelijat. Samalla he ovat alustan rakentama yleisötuote, primäärituotannolle portti yleisöihin ja kulttuurinkuluttajiin.

Ammattimaisten kirja-arvostelijoiden työn tulosta on ollut vaikeaa mitata yleisön reaktioin, kuten tykkäyksinä tai vierailijamäärinä, sillä arvostelijat jäävät journalististen juttujen verkkostatistiikkavertailuissa auttamattomasti alakynteen. Ensinnäkin institutionaalisen arvostelun yleisöt ovat jo lähtökohtaisesti marginaalisia, sillä kaikki eivät seuraa kaikkia kulttuurinlajeja ja arvosteluja seuraavat ovat eri kulttuurin lajien yleisöissäkin marginaalissa. Arvostelun edellä mainittu eksklusiivinen monologiretoriikka ei myöskään kutsu yleisöjä vuorovaikutteisuuteen. Tätä taustaa vasten alustatalouden käyttäjäarvosteluissa, jotka sinänsä eivät yleisövuorovaikutussuhteessaan kovinkaan poikkea verkkoyhteisöjen viestintätavoista, yleisösuhde näyttäytyy siten varsin toisenlaisena.

\section{Kulttuurinen inter- ja intramediaatio}

Edellä tarkastelimme käyttäjäarvostelijoiden toimintaa Instagram-alustalla neljän ulottuvuuden kautta: tuottaja-asema, sisällöt ja ilmaisutavat, tuotantokontekstit sekä yleisösuhde. Kaikissa näissä ulottuvuuksissa käyttäjäarvostelu erosi varsin merkittävästi institutionaalisammatillisen arvostelun merkityksistä. Näitä eroja on mahdollista luodata syvemmin tarkastelemalla perinteisiä arvostelijoita ja alustatalouden käyttäjäarvostelijoita osana sitä teoreettista kehikkoa, jossa arvostelua on perinteisesti käsitteellistetty. Kirjallisuusarvostelun instituutiota osana kulttuurituotantoa on nimittäin tullut kirjallisuuden- ja taiteensosiologiassa tavaksi kuvata seuraavan ketjun avulla (ks. kuvio 1): tuottaja (taiteilija), välittäjä (kriitikko), sisällöt (teksti) ja vastaanottaja (yleisö) (Duncan 1953, Hurri 1993, Niemi 1991, Jaakkola 2015). 
Malli kuvaa arvostelijan kulttuurista välittäjäfunktiota joukkoviestinnän aikakaudella, jota leimasivat mediaorganisaation keskeinen asema institutionaalisen järjestyksen luojana ja viestinnän yksisuuntaisuus toimittajalta/arvostelijalta yleisölle. Tässä mallissa korostuvat myös yksittäiset toimijat, ja mallin heikkoutena on muun muassa, että se häivyttää taustalle tuotannon rakenteet. Toisaalta digitaalisella aikakaudella ja sitä ennen organisaatioiden keskeinen asema sisällöntuotannon säätelijöinä voitiinkin ottaa annettuna. Alustatalouden infrastruktuurit toimivat kuitenkin perinteisestä instituutionaalisesta järjestyksestä poikkeavalla tavalla, minkä vuoksi kulttuurituotannon sitä osaa, johon viitataan tuotantokontekstina, on tarkasteltava vivahteikkaammin. Lisäksi primäärituotanto nähdään (esi-) digitaalisessa mallissa yksinkertaistettuna, eikä malli tee oikeutta sille, että yksittäinen tuottaja on osa moninaista tuotantoyhteisöä ja -ympäristöä sekä välityskoneistoa (kirjallisuusagentit, kustannustoimittajat, tiedottajat, promoottorit, messujärjestäjät ym.), joka asettuu välittäjäksi tekijän ja intermediaarisen välittäjän välille.

Kuvio 1. Kulttuurituotannon välitysketju eli kulttuurisen intermediaation malli.

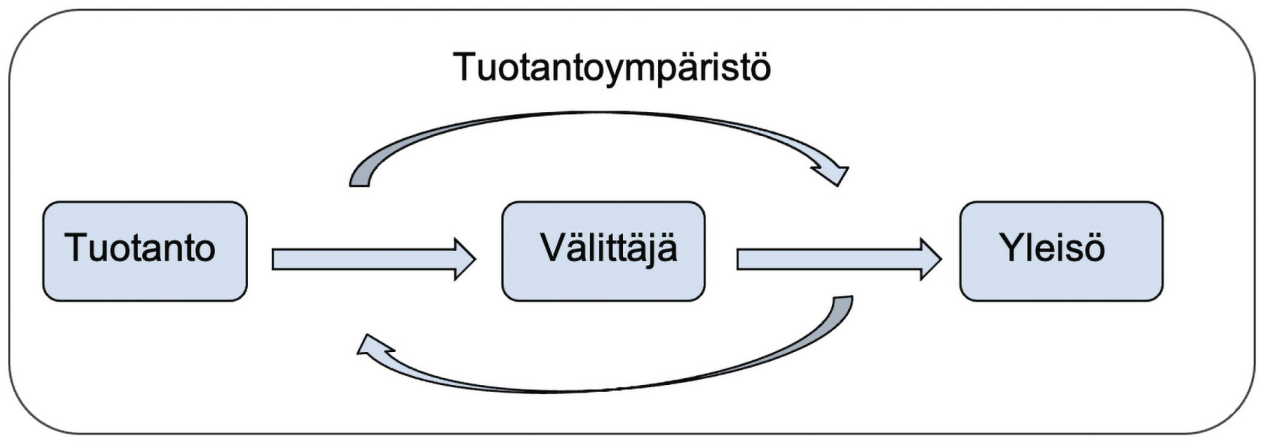

Miten käyttäjäarvostelijat suhteutuvat kulttuurisen intermediaation malliin? Voidaanko käyttäjäarvostelija samastaa suoraan kulttuuritoimituksen kriitikon rooliin vai toimiiko välitystoiminta institutionaalisessa organisaatiostruktuurissa ja alustataloudessa eri tavoin? Esitämme, että kulttuurisen intermediaation mallia on päivitettävä alustoituneen digitaalisen kulttuurituotannon aikakaudelle, jotta arvostelijan asemaa kulttuurisena välittäjänä voidaan paremmin kuvata alustataloudessa. Alustatalouden kirjallisuuskriitikissä keskeinen muutos verrattaessa perinteiseen institutionaaliseen kirjallisuuskritiikkiin on se, että mediaorganisaation keskeinen asema murtuu. Kuten sanottu, mediaorganisaatio ei enää aktiivisesti valikoi ja resursoi arvostelijoita eikä toimi siten kulttuurisen julkisuuden portinvartijana, vaan arvostelijaksi voi tulla kuka tahansa internetin käyttäjä. Arvostelutoiminnan tavoitteet, arvostelijan asemoituminen primäärituotannon ja vastaanoton väliin sekä tavat vedota yleisöihin ja rakentaa yleisöjä muuttuvat. Samalla kulttuurituotannon välitysketju ei kenties enää toimi samalla tavalla, sillä välittäjiksi ilmoittautuneiden toimijoiden välille syntyy suuria eroja heidän saavuttamassaan julkisuuden volyymissä, viestinnän tavoissa, yleisöissä ja sisältöjen laadussa.

Alustataloudessa välitysfunktioon vaikuttavat olennaisesti arvostelutoiminnan avoimuus, joka johtuu ohjailevien organisaatioiden erilaisesta toiminnallisesta asemasta, ja 
alustan tarjoamat affordanssit, joihin viittaamme kootusti termillä affordanssijärjestelmät. Kulttuurisen intermediaation malli perustuu keskeisesti inhimilliseen päätösvoimaan eli siihen, että arvostelijat, osana media-ammattilaisista ja taidemaailmasta koostuvia yhteisöjään, tekevät päätökset arvosteltavista kirjoista ja arvostelujensa sisällöistä. Alustoituneissa tuotannon rakenteissa mediaorganisaatiolla ei ole kuitenkaan valtaa valita arvostelijoita eivätkä arvosteltavia teoksia valitse nämä ammatillisen yhteisön valitsemat poikkeusyksilöt, vaan periaatteessa kuka tahansa voi ryhtyä käyttäjäarvostelijaksi, saada näkyvyyttä kirjalle tai kirjallisuuden lajille, kerätä ympärilleen yhteisön, joka osallistuu keskusteluun ja vie sitä eteenpäin arvostelun prosessia merkittävästi hajauttaen. Arvostelijaksi valikoituminen ja kasvaminen perustuu siten yhteisön legitimoivaan voimaan.

Yllä kuvatuista kulttuurituotantoketjun osa-alueista on huomattavissa, että käyttäjäarvostelijat poikkeavat monin paikoin kirjallisuusinstituution perinteisistä arvosteluista. Erot voidaan karkeasti tiivistää eroavaisuuksiin kulttuurisen intermediaation tavoitteissa ja suunnassa. Perinteisten arvostelijoiden pyrkimyksen edustavuuteen ja asemoitumiseen primäärituotannon ja vastaanottavan yleisön välille on korvannut pyrkimys olla osa vastaanottavaa yhteisöä valitulla alustalla. Toisistaan voidaan erottaa kulttuurinen inter- ja intramediaatio, joilla on erilaiset päämäärät ja jotka asemoivat arvostelijan eri tavoin, tuottaen erilaisen sisällön kautta erilaiset suhteet yleisöön ja primäärituotantoon. Kulttuurisen inter- ja intramediaation erot on kuvattu taulukkoon 2.

Taulukko 2. Kulttuurisen inter- ja intramediaation keskeisiä eroavaisuuksia.

\begin{tabular}{|l|l|l|}
\hline $\begin{array}{l}\text { Arvostelijan } \\
\text { positio tuotanto- } \\
\text { ketjussa }\end{array}$ & Intermediaatio & Intramediaatio \\
\hline Funktio & $\begin{array}{l}\text { Sisällön arvottaminen ja suhteuttami- } \\
\text { nen tuotantokontekstiinsa }\end{array}$ & $\begin{array}{l}\text { Omantaanottajan välissä } \\
\text { sanoittaminen ja jakaminen }\end{array}$ \\
\hline Tavoite & $\begin{array}{l}\text { Kulttuurin uutuustuotteiden historial- } \\
\text { lis-esteettisen arvon osoittaminen }\end{array}$ & $\begin{array}{l}\text { Vertaisrohkaisu ja oman elämäntavan } \\
\text { ylläpitäminen omaa kokemusta } \\
\text { avaamalla }\end{array}$ \\
\hline Muoto & Arvottaminen ja sen perustelut & $\begin{array}{l}\text { Yhteiskuluttaminen, jaettu } \\
\text { kuluttaminen }\end{array}$ \\
\hline
\end{tabular}

Jaakkola on tutkiessaan YouTuben (2018), Instagramin (2019, 2020b) ja Vimeon (2020c) arvostelijoita tuonut esiin intramediaation keskeisiä piirteitä (ks. myös Jaakkola 2021b, tulossa). Intramediaatiossa on kyse siitä, että kulttuurinen välittäjyys on vertaisviestintää, joka ei pyri suhteuttamaan kirjaa sen tuotantokontekstiin vaan yksittäisen arvostelijan reseptiokontekstiin. Reseptiokontekstina on yksittäisen julkiseen asemaan itsensä asettavan lukijan elämänpiiri: henkilökohtainen lukukokemus osana välitöntä elinympäristöä, 
jonka muodostavat koti ja perhe, ja osana omaa henkilökohtaista reseptiohistoriaa. Lukijalähtöinen arviointi alkaa lukijayhteisöstä ja palaa siihen; arvostelija ei asetu samalla lailla välikädeksi tuotannon ja vastaanoton alueiden välille kuin institutionalisoituneet arvostelijat kulttuurisen intermediaation klassisessa asetelmassa. Kulttuurisessa intramediaatiossa arvostelija pyrkii olemaan kuin vastaanottajansa, yksi heistä, ja häivyttämään kaikin tavoin rajaa näiden välillä, kuten edellä on esitetty. Rajatyö, jota käyttäjäarvostelija tekee, on siten hyvin inklusiivista.

Intramediaation tehtävänä on pitää yllä faattista ja parasosiaalista suhdetta lukijoiden välillä, antaa tukea ja inspiraatiota lukuharrastukseen ja luoda emotiaalinen yhteys, joka voi intensiivisimmillään johtaa kiintymystilan (affinity space) luomiseen (Gee 2004). Geen (emt.) mukaan kiintymystila on affektiivinen, käyttäjiä toisiinsa emotionaalisesti sitova tila, joka tekee mahdolliseksi uuden oppimisen. Tällaisessa tilassa vertaisten on luontevaa jakaa oppimisiaan muille, tarjota kannustusta ja rohkaisua. Vertaisrohkaisun ja viime kädessä vertaisoppimisen elementti onkin intramediaatiota keskeisesti määrittävä elementti. Arvostelija ei asetu yleisöstään erilliseksi mielipideauktoriteetiksi vaan pyrkii olemaan elämänpiirissään läsnä muille kertomalla omasta kokemuksestaan, jonka tiedostaa olevan vain yksi monista mahdollisista kokemuksista. Sosiaalisen lukemisen tavoin kyse on yhteiskuluttamisesta, sosiaalisesta tai jaetusta kuluttamisesta, joka tulee näkyväksi arvostelijan aktiivisen viestinnän kautta.

Kulttuurisessa intermediaatiossa arvostelija taas pyrkii lähtökohtaisesti tarttumaan teoksen sisältöön, kuvaamaan, tulkitsemaan ja arvottamaan sitä sekä asettamaan sen ajalliseen yhteyteensä. Orlikin (2016) mukaan tuo ajallinen yhteys koostuu teoksen sijoittamisesta historialliseen tuotantokontekstiinsa. Samalla arvostelija pyrkii häivyttämään taustalla vaikuttaneet tekijät itse arvostelusta: hän ei aktiivisesti nosta esiin lähteitään tai niitä neuvotteluja, jotka hän on käynyt läpi lähdeorganisaation kanssa, vastaanoton olosuhteita tai ympäristöä, jossa vastaanotto on tapahtunut. Henkilökohtainen taso manifestoituu tunteina ja ajatuksina mutta ei saa sijaa materiaalisessa ulottuvuudessa. Arvostelijan ja vastaanottajan asema on myös eriytynyt siten, että arvostelija ei koe olevansa kuka tahansa kulttuurinkuluttaja vaan tietoinen käyttämästään vallasta. Hän pyrkii osoittamaan distinktiota toimimalla hyvän maun edustajana, opastajana ja opettajana.

Alustoitunut arvostelutoiminta seurailee pitkälti käyttäjälähtöisen sisällöntuotannon tunnusmerkkejä (Bruns 2016). Siinä on elementtejä osallistavasta kulttuurista (Jenkins 2007), vernakulaarisesta luovuudesta (Burgess 2007) ja affektiivisesta työstä (Gee 2004), joita on kaikkia käytetty kuvaamaan virtuaaliyhteisöjen sisällöntuotantoa. Alustojen, kuten Instagramin, affordanssijärjestelmät kannattelevat keskeisesti näitä piirteitä, jotka puolestaan vaikuttavat kulttuurisen intermediaation painopisteen muuttumiseen.

Kun intermediaatiossa välittävä organisaatio toimii arvostelijan riippumattomuuden takaajana - hyötyen toki arvostelijan toiminnasta toisella tavalla voidessaan myydä sisältöä yleisöille ja mainostajille - intramediaatiossa arvostelijat toimivat alustatalouden mekanismeille alisteisina ja heidän tuottamansa yhteisö on hyödynnettävää dataa. Arvostelutoiminnassa tulevat näkyviksi käyttäjien elämäntyylit ja niihin kytkeytyvä yhteiskunnallinen maku. Esimerkiksi valinnat arvostella jokin tietty kirja tai seurata tiettyä kirjallisuuden lajityyppiä tai kirjailijakuntaa, kuten myös päätökset näyttää kotia ja avata muita kulutustottumuksiaan osana arvostelutoimintaa, kertovat käyttäjän edustamasta kulttuurista, elämäntyylistä 
ja mausta sosiologisessa mielessä (ks. Purhonen, Gronow ja Heikkilä 2014). Tämä johtaa siihen, että käyttäjiä voidaan profiloida ja heidän makuprofiilinsa ovat mahdollisesti käypää dataa tiettyjen tuoteryhmien ja kulttuurituotteiden markkinoijille. Osittain käyttäjät kertovat itse oma-aloitteisesti valitsemiensa kaupallisten yhteistyösuhteiden kautta, minkälaisia tuotteita he suosivat. Aineistossa Instagram-arvostelijoilla oli kaupallisia yhteistöitä esimerkiksi äänikirjapalvelujen tarjoajien, kuuloke- ja kaiutinvalmistajien sekä festivaalijärjestäjien ja muiden tapahtumatuottajien kanssa. Osa kirja-arvostelijoista oli myös erikoistunut tiettyyn aihepiiriin kuten ruoka- tai juoksukirjoihin, mikä avasi yhteistyömahdollisuuksia näihin verrattain fyysis-materiaalisiin tuotepiireihin. Osittain kyse on hienovaraisemmista vihjeistä, kuten tuotemerkin valinnoista, joista voi niin ikään tehdä johtopäätöksiä käyttäjän kulutustottumuksista. Käyttäjäarvostelijat ovat siten alttiita sille, että heidän dataansa myydään kolmansille osapuolille. Voidaan todeta, että myös kirja-arvostelija asettuu alustakapitalismin (ks. Srnicek 2016) logiikan mukaisesti kauppatavaraksi.

\section{Keskustelu}

Kulttuurinen inter- ja intramediaatio pyrkivät käsitteinä kuvaamaan arvostelijoiden erilaista asemoitumista kulttuurituotannon ketjussa - intermediaatiossa tuotannon puoleen, intramediaatiossa vastaanoton. Näillä asemoitumisilla on omat tavoitteensa ja erityispiirteensä. Kaikkea alustoitunutta arvostelutoimintaa ei voi kuitenkaan lähtökohtaisesti määritellä intramediaatioksi, koska tämä merkitsisi käyttäjäarvosteluiden määrittelemistä liian kapeaalaisesti. Käyttäjäarvostelijoilla voi olla myös tavoitteita toimia intermediaation nimissä, ja monesti puhuttaessa kehityksestä amatööristä ammattilaiseksi tai amatöörimäisen sisällöntuotannon muodollistumisesta (Burgess 2007) kyse onkin liukumasta intramediaatiosta kohti intermediaatiota. Käsitteillä on siten yhteyksiä myös keskusteluun asiantuntijuudesta, mitä on käyty sosiaalisen median välittäjistä (ks. esim. Kristensen, From ja Haastrup 2020, Verboord 2010).

Inter- ja intermediaatiolla saatetaan helposti tulkita olevan laatuero perinteisen arvostelun kriteereiden ehdoin siten, että intermediaatio on arvostelutoiminnan jalostunut ja laadukas muoto kun taas intramediaatio on laadutonta amatööriviestintää. Käsitteiden on kuitenkin tarkoituksena eritellä toiminnot siten, että voidaan puhua erilaisista välitystoiminnan muodoista, joilla on eri tavoitteet ja laatukriteerit. Kyse on toisin sanoen kahdesta eri ilmiöstä: ylhäältä alaspäin tuotetusta sisällöntuotannosta, joka on tyypillisesti ollut ammattimaisen toiminnan määre, ja ruohonjuuritasolla kasvavasta vertaissisällöntuotannosta, jota on tavattu kutsua amatööriviestinnäksi. Kummallakin arvostelutoiminnan muodolla on nykyään kulttuurista valtaa määritellä sitä, miten kirjamarkkinoiden uusista tuotteista puhutaan ja miten niitä arvotetaan.

Kulttuurisesta intermediaatiosta on jo muutaman vuosikymmenen ajan käyty kiivasta keskustelua, jossa käsitteen on väitetty vesittyneen ja muuttuneen kaikenkattavaksi (ks. esim. Jaakkola 2015). Erottamalla nyansseja välittäjän asemissa on mahdollista päästä lähemmin kuvaamaan sitä, mistä välitystoiminnassa on kyse. Näemme siksi erottelulla olevan kauaskantoista merkitystä ja sen lisäävän ymmärrystä alustoituneesta arvostelutoiminnasta myös muilla kulttuurin välittämisen osa-alueilla kuin kirjallisuudessa ja sen kritiikissä. 
Käsitteet antavat välineitä myös pohtia arvostelutoiminnan kehittämistä. Voidaan edelleen ajatella, että täyttääkseen arvostelun tai jopa kritiikin tunnusmerkit arvostelun on välitettävä tuotteestaan jokin arvio ja arvion on oltava todistetusti puolueeton, vääristymätön, ei-korruptoitunut. Intermediaalinen arvostelu perustuu viime kädessä arvostelijan puolueettomaan arvioon, jota eivät vääristä erilaiset kaupalliset velvollisuudet tai lojaalisuudet. Vertaisarvosteluissa saattaa toki periaatteessa riittää pelkkä autenttisuus ja parasosiaalisen suhteen rakentaminen seuraajaan, mutta jos arvostelulta vaaditaan enemmän, niiltä voidaan edellyttää myös eettisyyttä, vastuullisuutta ja avoimuutta. Tätä arvostelija voi edistää refleksiivisyydellä, tuomalla oman toimintansa periaatteita esiin. Monet kirjojen käyttäjäarvostelijat pyrkivät kyllä avaamaan arvioidensa perusteita säännöllisin metakommentein, kuvaamalla taustakytköksiään erikseen jollain alustalla tai merkitsemällä yksittäisen julkaisun ja kirjavalinnan kytkökset näkyviin. Käyttäjäarvostelujen laadun kohentaminen laajemmalla rintamalla edellyttäisi yhteisen, riippumattoman eettisen standardin rakentamista.

\section{Johtopäätökset}

Käyttäjälähtöiset kirja-arvostelut alustataloudessa tuovat esille uudenlaisen tuottajaposition, jossa arvostelijan on asetuttava osaksi alustatalouden logiikkaa ja yksityisyrittäjämäisesti hallittava profiliaan mikromediana, mikä tarkoittaa sitä, että arvostelijan on luotava suhde sellaisiiin asioihin, jotka institutionaalisessa arvostelun genressä eivät ole ajankohtaisia: kaupallisuuteen, yleisövuorovaikutukseen ja henkilökohtaiseen yleisötyöhön. Käyttäjälähtöiset kirja-arvostelut sijoittuvat myös toisenlaiseen kontekstiin, joka on arkinen ja intiiimi. Ne tuovat siten esille paitsi uuden yleisö-, myös kirjasuhteen.

Käyttäjälähtöinen arvostelutoiminta on keskeisiltä piirteiltään alustoitunutta ja dataistunutta, ja se on sekä primäärituotannolle että yhteiskunnalle yhä tärkeämmäksi muodostuva julkinen väylä uusista kulttuurituotteista puhumiseen ja niiden arvottamiseen. Näin ollen alustojen toimintalogiikan ymmärtäminen arvosteluekosysteemissä on tärkeää. Käyttäjälähtöinen arvostelutoiminta on riippuvaista ensinnäkin valituista alustoista, joiden elinkaari voi olla lyhytkin, ja toiseksi genreviestintään vakiintuneiden alustojen affordansseista, jotka saattavat muuttua nopeastikin. Arvostelugenre nojaa alustataloudessa jatkuvasti muuttuviin käytäntöihin ja on siten luonteeltaan varsin dynaaminen, kun institutionaalinen arvostelun genre on pysynyt koko historiansa ajan hyvin staattisena, eikä digitalisaatiokaan ei ole tuonut tähän suuria muutoksia. Lisää tutkimusta tarvitaan siitä, miten arvostelu muuntuu eri alustoille eli miten arvostelijat käyttävät alustoja teosten arvioimiseen, sekä sitä, miten alustat hyödyntävät arvosteluyhteisöjä kolmansien osapuolien tarkoituksiin. Tässä artikkelissa olemme kiinnittäneet huomiota vain kirjallisuusarvosteluihin ja Instagramiin.

Alustojen kirjaharrastajia pidetään julkisissa keskusteluissa helposti harmittomina maallikkoina, mutta väitämme, että lukukokemusten jakaminen ja työstäminen sekä lajityyppien monipuolistaminen ovat arvokkaita itsessään, sillä ne pitävät omalta osaltaan kirjakulttuuria ja lukemisharrastusta elävänä. Käyttäjäarvostelijoilla on myös kasvavaa kulttuurista valtaa nostaa esiin tai vaieta uusia kulttuurituotteita sekä tuottaa niistä puhumisen tapoja ja jopa arvottaa teosten sisältöjä, vaikkei itse arvottaminen keskeinen tavoite olekaan. Käyttäjädataa on helppo puolustaa tärkeänä tietona kulttuuriteollisuudelle, mutta on pidettävä 
huolta siitä, ettei dataa hyödynnetä myös sellaisiin tarkoituksiin, joihin sitä ei ole tarkoitettu. Onneksi voidaan ainakin kuvitella tulevaisuus, jossa dataistumisen suuntaa voitaisiin kääntää niin, etteivät toiminnasta hyödy pelkästään alustajätit vaan myös yksilöt ja esimerkiksi marginaaliset kulttuurin muodot. Aktiivisen algoritmeihin vaikuttamisen rinnalle tarvitaan todennäköisesti kulttuuriälykkäitä ja -herkkiä alustatoimijoita ja teknologioita.

\section{Kirjallisuus}

Barbour, Kim ja Lydia Heise. 2019. Sharing \#home on Instagram. Media International Australia 172 (1): 35-47. https://doi.org/10.1177/1329878x19853305.

Blank, Grant. 2007. Critics, ratings, and society: The sociology of reviews. Lanham: Rowman \& Littlefield Publishers.

Boot, Peter. 2011. Towards a genre analysis of online book discussion: Socializing, participation and publication in the Dutch booksphere. Selected Papers of Internet Research. Chicago: Association of Internet Researchers (AoIR).

Bourdieu, Pierre. 2010/1979. Distinction: A social critique of the judgement of taste. Abingdon: Routledge.

Bruns, Axel. 2016. User-generated content. Teoksessa The international encyclopedia of communication theory and philosophy, toimittaneet Klaus Bruhn Jensen, Robert T. Craig, Jefferson D. Pooley ja Eric W. Rothenbuhler, 1-5. Oxford: Wiley-Blackwell.

Burgess, Jean. 2007. Vernacular creativity and new media. Väitöskirja. Brisbane: Queensland University of Technology.

Couldry, Nick ja Ulises A. Mejias. 2019. The cost of connectivity. How data is colonizing human life and appropriating it for capitalism. Stanford: Stanford University Press. https://doi.org/10.1080/15295036.2020.1718835.

Deeb-Swihart, Julia, Christopher Polack, Eric Gilbert ja Irfan Essa. 2017. Selfie-presentation in everyday life: A large-scale characterization of selfie contexts on Instagram. Proceedings of the International AAAI Conference on Web and Social Media, 11 (1). Luettu 2.5.2021. https://ojs.aaai.org/index.php/ICWSM/article/view/14896.

Duncan, Hugh Dalziel. 1953. Language and literature in society: A sociological essay on theory and method in the interpretation of linguistic symbols with a bibliographical guide to the sociology of literature. Chicago: University of Chicago Press.

Fuller, Daniel ja Sedo DeNel Rehberg. 2013. Reading beyond the book: The social practices of contemporary literary culture. London: Routledge.

Gee, James Paul. 2004. Situated language and learning: A critique of traditional schooling. Lontoo: Routledge.

Gibson, James Jerome. 1979. The ecological approach to visual perception. Boston: Houghton Mifflin.

Gillespie, Tarleton. 2019. Custodians of the Internet: Platforms, content moderation, and the decisions that shape social media. London: Yale University Press.

Helmond, Anne. 2015. The platformization of the web: Making web data platform ready. Social Media + Society (July-December): 1-11. https://doi.org/10.1177/2056305115603080.

Hepp, Andreas. 2020. Deep mediatization. London: Routledge.

Herkman, Juha ja Eliisa Vainikka. 2012. Lukemisen tavat: Iukeminen sosiaalisen median aikakaudella. Tampere: Tampere University Press.

Himma-Kadakas, Marju, Allan Rajavee, Maarja-Liis Orgmets, Linda Eensaar ja Ragne Kõuts-Klemm. 2018. The food chain of YouTubers: Engaging audiences with formats and genres. Observatorio 12: 54-75. https://doi.org/10.15847/obsobsooo1385.

Hurri, Merja. 1993. Kulttuuriosasto: symboliset taistelut, sukupolvikonflikti ja sananvapaus viiden pääkaupunkilehden kulttuuritoimituksissa 1945-1980. Väitöskirja. Tampere: Tampereen yliopisto.

Hutchinson, Jonathon. 2017. Cultural intermediaries: Audience participation in media organisations. Cham: Palgrave Macmillan.

Jaakkola, Maarit. 2015. The contested autonomy of arts and journalism: Change and continuity of the dual professionalism of cultural journalism. Väitöskirja. Tampere: Tampere University Press.

Jaakkola, Maarit. 2018. Vernacular reviews as a form of co-consumption: User-generated review videos on YouTube. MedieKultur - Journal of Media and Communication Research 34 (65): 10-30. https://doi.org/10.7146/mediekultur.v34i65.104485. 
Jaakkola, Maarit. 2019. From re-viewers to me-viewers: The \#Bookstagram review sphere on Instagram and the perceived uses of the platform and genre affordances. Interactions: Studies in Communication and Culture 10 (1-2): 91-110. https://doi.org/10.1386/iscc.10.1-2.91_1.

Jaakkola, Maarit. 2020a. From vernacularized commercialism to kidbait: Toy review videos on YouTube and the problematics of the mash-up genre. Journal of Children and Media 14 (2): 237-254. https://doi.org/10.1080/17482798.2019.1693409.

Jaakkola, Maarit. 202ob. Oman lukukokemuksensa visualisoijat: käyttäjälähtöiset kirjallisuusaiheiset arvostelut Instagramissa. Kulttuurintutkimus 36 (3): 31-44.

Jaakkola, Maarit. 2020c. Useful creativity: Vernacular reviewing on the video-sharing platform Vimeo. Culture Unbound: Journal of Current Cultural Research 12 (2): 373-392. https://doi.org/10.3384/cu.2000.1525.20200420a.

Jaakkola, Maarit. 2021a, tulossa. Content analysis of cultural coverage. Teoksessa Handbook of standardised content analysis, toimittaneet Franziska Oehmer, Sabrina Heike Kessler, Edda Humprecht, Katarina Sommer ja Laia Castro Herrero. Wiesbaden: Springer VS.

Jaakkola, Maarit. 2021b, tulossa. Reviewing culture online: Post-professional cultural critique across platforms. London: Palgrave Macmillan.

Jaakkola, Maarit ja Tiina Räisä. 2019. Book lovers, book worms and bookaholics: Self-presentations of reading in the book reviewing community on Instagram. NordMedia 2019: Communication, Creativity Q Imagination Challenging the Field, 22 August 2019, Malmö, Sweden.

Janssen, Susanne. 1997. Reviewing as social practice: Institutional constraints on critics' attention for contemporary fiction. Poetics 24 (5): 275-297. https://doi.org/10.1016/s0304-422x(96)ooo10-1.

Janssen, Susanne ja Marc Verboord. 2015. Cultural mediators and gatekeepers. Teoksessa International Encyclopedia of the Social Q Behavioral Sciences, 2. painos,.toimittaneet Neil Smelser ja Paul Baltes, 440446. Amsterdam: Elsevier. https://doi.org/10.1016/b978-0-08-097086-8.10424-6.

Jenkins, Henry. 2007. Confronting the challenges of participatory culture: Media education for the 21st century (part one). Nordic Journal of Digital Literacy 2: 23-33. https://doi.org/10.18261/issn1891-943X-2007-01-03.

Jones, Phil, Beth Berry ja Paul Long, toim. 2019. Cultural intermediaries connecting communities: Revisiting to approaches of cultural engagement. Bristol: Policy Press.

https://doi.org/10.1332/policypress/9781447344995.001.0001.

Kammer, Aske. 2015. Post-industrial cultural criticism: The everyday amateur expert and the online cultural public sphere. Journalism Practice 9 (6): 872-889. https://doi.org/10.1080/17512786.2015.1051371.

Kolehmainen, Marjo ja Katariina Mäkinen. 2019. Affective labour of creating atmospheres. European Journal of Cultural Studies 24 (2): 448-463. https://doi.org/10.1177/1367549419886021.

Kristensen, Nete Nørgaard, Unni From ja Helle Kannik Haastrup, toim. 2020. Rethinking cultural critique: New voices in the digital age. New York: Palgrave Macmillan. https://doi.org/10.1007/978-981-15-7474-0_1.

Leaver, Tama, Tim Highfield ja Chrystal Abidin. 2020. Instagram: Visual social media cultures. New York: Wiley. https://doi.org/10.1080/o8949468.2021.1908181.

Lehtonen, Mikko. 2001. Post scriptum: kirja medioitumisen aikakaudella. Tampere: Vastapaino.

Lupton, Deborah. 2016. The quantified self. Cambridge: Polity Press.

Luoma-aho, Vilma, Tuisku Pirttimäki, Devdeep Maity, Juha Munnukka ja Hanna Reinikainen. 2019. Primed authenticity: How do vlog audiences view the authenticity of influencers and sponsoring brands? International Journal of Strategic Communication 13 (4): 352-365. https://doi.org/10.1080/1553118x.2019.1617716.

Manovich, Lev. 2000. Macro-media and micro-media. Luettu 2.5.2021 http://manovich.net/index.php/projects/macro-media-and-micro-media.

Manovich, Lev. 2017. Instagram and contemporary image. Luettu 2.5.2021. http://manovich.net/index.php/projects/instagram-and-contemporary-image.

Murray, Simone. 2018. The digital literary public sphere: Reading, writing, and selling books in the internet era. Baltimore: John Hopkings University Press.

Mäkinen, Ilkka. 2014. Reading like monks: The death or survival of the love of reading? Teoksessa Reading in changing society: Studies in reading and book culture, toimittaneet Marjut Lauristin ja Peeter Vihalemm, 13-27. Tartu: University of Tartu Press. https://doi.org/10.26530/oapen_49679o.

Nieborg, David B. ja Thomas Poell. 2018. The platformization of cultural production: Theorizing the contingent cultural commodity. New Media Q Society 20 (11): 4275-4292. https://doi.org/10.1177/1461444818769694.

Niemi, Juhani. 1991. Kirjallisuus instituutiona: johdatus sosiologiseen kirjallisuudentutkimukseen. Helsinki: Suomalaisen kirjallisuuden seura. 
Orlik, Peter B. 2016. Media criticism in a digital age: Professional and consumer considerations. London: Taylor \& Francis.

Prinsloo, Mastin ja Mignonne Breier. 1996. The social uses of literacy: Theory and practice in contemporary South Africa. Amsterdam: John Benjamins Publishing Company.

Purhonen, Semi, Jukka Gronow ja Riie Heikkilä. 2014. Suomalainen maku: kulttuuripääoma, kulutus ja elämäntyylien sosiaalinen eriytyminen. Gaudeamus.

Rodnek, Nicola. 2019. From bookshelf porn and shelfies to \#bookfacefriday: How readers use Pinterest to promote their bookishness. Participations 16 (1): 473-495.

Smith Maguire, Jennifer ja Julian Matthews, toim. 2014. Cultural intermediaries reader. London: Sage.

Srnicek, Nick. 2016. Platform capitalism. Cambridge: Polity Press.

Steiner, Ann. 2008. Private criticism in the public space: Personal writing on literature in readers' reviews on Amazon. Participations 5 (2).

Steiner, Ann. 2010. Personal readings and public texts: Book blogs and online writing about literature. Culture Unbound: Journal of Current Cultural Research 2 (1): 471-494. https://doi.org/10.3384/cu.2000.1525.10228471.

Tomasena, José M. 2019. Negotiating collabxorations: BookTubers, the publishing industry, and YouTube's ecosystem. Social Media + Society, 5 (4). https://doi.org/10.1177/2056305119894004.

van Dijck, José. 2014. Datafication, dataism and dataveillance. Data between scientific paradigm and ideology. Surveillance Q Society 12 (2): 197-208. https://doi.org/10.24908/ss.v12i2.4776.

van Dijck, José. 2020. Seeing the forest for the trees: Visualizing platformization and its governance. New Media and Society (July 2020). https://doi.org/10.1177/1461444820940293.

van Dijck, José ja Thomas Poell. 2018. The platform society: Public values in a connective world. Oxford: Oxford University Press.

Verboord, Marc. 2010. The legitimacy of book critics in the age of the Internet and omnivorousness: Expert critics, Internet critics and peer critics in Flanders and the Netherlands. European Sociological Review 26 (6): 623-637. https://doi.org/10.1093/esr/jcpo39.

Wahl-Jorgensen, Karin. 2012. The strategic ritual of emotionality: A case study of Pulitzer Prize-winning articles. Journalism 14 (1): 129-145. https://doi.org/10.1177/1464884912448918.

Waugh, Patricia, toim. 2006. Literary theory and criticism. Oxford: Oxford University Press.

Wenger, Etienne. 1998. Communities of practice: Learning, meaning, and identity. Cambridge: Cambridge University Press. 